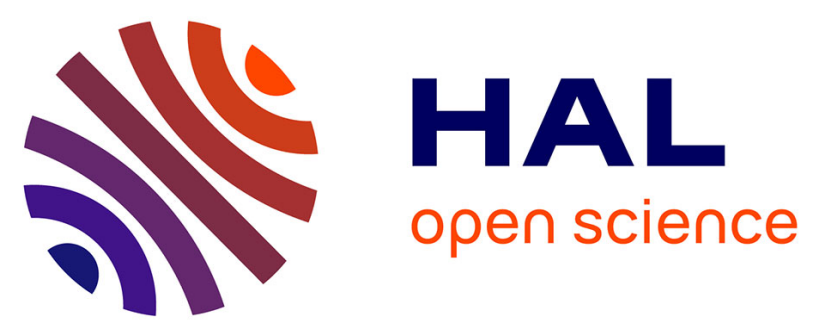

\title{
Structure and reactivity of As(III)- and As(V)-rich schwertmannites and amorphous ferric arsenate sulfate from the Carnoule's acid mine drainage, France: Comparison with biotic and abiotic model compounds and implications for As remediation
}

Fabien Maillot, Guillaume Morin, Farid Juillot, Odile Bruneel, Corinne Casiot, Georges Ona-Nguema, Yuheng Wang, Sophie Lebrun, Emmanuel Aubry, Gilberto Vlaic, et al.

\section{To cite this version:}

Fabien Maillot, Guillaume Morin, Farid Juillot, Odile Bruneel, Corinne Casiot, et al.. Structure and reactivity of $\mathrm{As}(\mathrm{III})$ - and $\mathrm{As}(\mathrm{V})$-rich schwertmannites and amorphous ferric arsenate sulfate from the Carnoule's acid mine drainage, France: Comparison with biotic and abiotic model compounds and implications for As remediation. Geochimica et Cosmochimica Acta, 2013, 104, pp.310-329. 10.1016/j.gca.2012.11.016 . hal-01018059

\section{HAL Id: hal-01018059 \\ https://hal.science/hal-01018059}

Submitted on 18 Jan 2022

HAL is a multi-disciplinary open access archive for the deposit and dissemination of scientific research documents, whether they are published or not. The documents may come from teaching and research institutions in France or abroad, or from public or private research centers.
L'archive ouverte pluridisciplinaire HAL, est destinée au dépôt et à la diffusion de documents scientifiques de niveau recherche, publiés ou non, émanant des établissements d'enseignement et de recherche français ou étrangers, des laboratoires publics ou privés. 


\title{
Structure and reactivity of $\mathrm{As}(\mathrm{III})-$ and $\mathrm{As}(\mathrm{V})$-rich schwertmannites and amorphous ferric arsenate sulfate from the Carnoulès acid mine drainage, France: Comparison with biotic and abiotic model compounds and implications for As remediation
}

\author{
Fabien Maillot ${ }^{\mathrm{a}}$, Guillaume Morin ${ }^{\mathrm{a}, *}$, Farid Juillot ${ }^{\mathrm{a}}$, Odile Bruneel ${ }^{\mathrm{b}}$, \\ Corinne Casiot $^{\mathrm{b}}$, Georges Ona-Nguema ${ }^{\mathrm{a}}$, Yuheng Wang ${ }^{\mathrm{a}}$, Sophie Lebrun ${ }^{\mathrm{a}}$, \\ Emmanuel Aubry ${ }^{\mathrm{c}}$, Gilberto Vlaic ${ }^{\mathrm{d}}$, Gordon E. Brown Jr. ${ }^{\mathrm{e}, \mathrm{f}}$ \\ a Institut de Minéralogie et de Physique des Milieux Condensés (IMPMC), UMR CNRS 7590, UPMC, 4 Place Jussieu, \\ 75252 Paris Cedex 05, France \\ ${ }^{\mathrm{b}}$ Laboratoire HydroSciences Montpellier (HSM), UMR 5569 CNRS-IRD-UMI\&2, Université Montpellier 2, Place E. Bataillon, CC \\ MSE, 34095 Montpellier Cedex 05, France \\ ${ }^{\mathrm{c}}$ Biogéochimie et Ecologie des Milieux Continentaux (Bioemco), UMR 7618 Université Paris 6, INRA, INAPG, CNRS, ENS, ENSCP, \\ Case 120, Tour 56, couloir 56-66, $4^{\text {ème }}$ étage, 4 place Jussieu, 75252 Paris cedex 05, France \\ ${ }^{\mathrm{d}}$ Department of Chemical Science, University of Trieste, Trieste I-34127, Italy \\ 'Surface \& Aqueous Geochemistry Group, Department of Geological \& Environmental Sciences, Stanford University, Stanford, \\ CA 94305-2115, USA \\ ${ }^{\mathrm{f}}$ Department of Photon Science and Stanford Synchrotron Radiation Lightsource, SLAC National Accelerator Laboratory, 2575 Sand Hill \\ Road, Menlo Park, CA 94025, USA
}

\begin{abstract}
Poorly ordered nanocrystalline hydroxysulfate minerals of microbial origin, such as schwertmannite, $\mathrm{Fe}_{8} \mathrm{O}_{8}(\mathrm{OH})_{6} \mathrm{SO}_{4}$, are important arsenic scavengers in sulfate-rich acid mine drainage (AMD) environments. However, despite the fact that $\mathrm{As}(\mathrm{III})$ and $\mathrm{As}(\mathrm{V})$ have been shown to sorb on schwertmannite, little is known about the actual mechanism of arsenic scavenging processes after microbial $\mathrm{Fe}$ (II) oxidation in AMD environments. The major focus of the present study is to determine the molecular-level structure of poorly ordered $\mathrm{As}(\mathrm{III})$ and $\mathrm{As}(\mathrm{V})$ bearing $\mathrm{Fe}$ oxyhydroxysulfate minerals from the Carnoulès AMD, France, which exhibits exceptional As(III) concentrations. Powder X-ray diffraction (XRD) and extended X-ray absorption fine structure (EXAFS) spectroscopy were used to compare field samples with a large set of synthetic analogs prepared via biotic or abiotic pathways, with $\mathrm{As} / \mathrm{Fe}$ ratios typical of minerals and mineraloids ranging from nanocrystalline schwertmannite to amorphous hydroxysulfate compounds. Our results yield further evidence for the poisoning effect of $\mathrm{As}(\mathrm{V})$ in limiting the nucleation of schwertmannite. For initial dissolved $\mathrm{As}(\mathrm{V}) / \mathrm{Fe}(\mathrm{III})$ molar ratios $\geqslant 0.2$, amorphous $\mathrm{Fe}(\mathrm{III})-\mathrm{As}(\mathrm{V})$ hydroxysulfate forms, with a local structure consistent with that of amorphous ferric arsenate. EXAFS data for this amorphous material are consistent with corner-sharing $\mathrm{FeO}_{6}$ octahedra to which $\mathrm{AsO}_{4}$ tetrahedra attach via double-corner ${ }^{2} \mathrm{C}$ linkages. For $\mathrm{As}(\mathrm{V}) / \mathrm{Fe}(\mathrm{III})$ molar ratios lower than $0.2, \mathrm{As}(\mathrm{V})$ binds to schwertmannite via ${ }^{2} \mathrm{C}$ surface complexes. In contrast with the $\mathrm{As}(\mathrm{V})$-containing samples, $\mathrm{As}(\mathrm{III})$ has a lower affinity for schwertmannite following its nucleation, as this mineral phase persists up to an initial $\mathrm{As}(\mathrm{III}) / \mathrm{Fe}(\mathrm{III})$ molar ratio of 0.6. EXAFS data indicate that during
\end{abstract}

\footnotetext{
* Corresponding author.

E-mail address: guillaume.morin@impmc.upmc.fr (G. Morin).
} 
the precipitation process, $\mathrm{As}(\mathrm{III})$ forms dominantly ${ }^{2} \mathrm{C}$ surface complexes on schwertmannite surfaces, likely on the sides of double-chains of $\mathrm{Fe}(\mathrm{III})(\mathrm{O}, \mathrm{OH})_{6}$ octahedra, with a smaller proportion of edge-sharing ${ }^{2} E$ surface complexes at the apexes of these chains. Importantly, dissolved $\mathrm{As}(\mathrm{V})$ concentrations in contact with $\mathrm{As}(\mathrm{V})$-schwertmannite or ferric arsenate were found to be $\sim 10$ times lower than dissolved As(III) concentrations in contact with As(III)-schwertmannite for similar As/ $\mathrm{Fe}$ ratios in the solid phase. Consequently, remediation of As-rich AMD environments is greatly improved by oxidation of $\mathrm{As}(\mathrm{III})$ to $\mathrm{As}(\mathrm{V})$.

\section{INTRODUCTION}

Arsenic is toxic to humans and is naturally released at Earth's surface from volcanic activity and from the chemical weathering of rocks, as well as from mining and industrial activities (Vaughan, 2006). Thanks to detailed investigations of such As-impacted environments as well as extensive laboratory studies, much progress has recently been made in understanding the relationship between arsenic crystal chemistry and its speciation and distribution at Earth's surface. Among other major processes affecting the fate of arsenic in the environment, arsenic scavenging by iron-bearing minerals has been shown to play an important role in delaying the long-term transfer of this element to surface- and groundwaters. Arsenic trapping associated with iron-bearing minerals has been observed in natural and polluted soils as well as in acid mine drainage (AMD) systems and hot springs (Morin and Calas, 2006; and references therein). Among these systems, AMDs have received much attention because they can locally produce high levels of dissolved arsenic in surface waters. Indeed, in AMDs, acidic $\mathrm{Fe}^{2+}$ - and $\mathrm{SO}_{4}{ }^{2-}$-rich waters originating from the oxidation of sulfide-bearing rocks can often carry high concentrations of dissolved As(III) resulting from dissolution of arsenopyrite or As-rich pyrite. In such sulfateand iron-rich acidic waters, arsenic is mainly trapped by sorption and/or coprecipitation, with ferric oxyhydroxysulfates and oxyhydroxides formed via the oxidation of dissolved $\mathrm{Fe}^{2+}$ (e.g., Jambor and Blowes, 1994; Nordstrom and Alpers, 1999). This iron oxidation reaction has been demonstrated to often be catalyzed by the metabolic activity of acidophilic microorganisms such as Acidithiobacillus ferrooxidans (e.g., Leblanc et al., 1996; Duquesne et al., 2003; Morin et al., 2003). Moreover, oxidation of As(III) to $\mathrm{As}(\mathrm{V})$, which is less toxic than the reduced form and less soluble in low $\mathrm{pH}$ waters, can be catalyzed by arsenite-oxidizing bacteria such as Thiomonas sp. (Battaglia-Brunet et al., 2002; Morin et al., 2003; Arsène-Ploetze et al., 2010; Bruneel et al., 2011). Such microbial oxidation has recently been suggested to play a key role in the natural attenuation of arsenic in the heavily contaminated Carnoulès AMD (Egal et al., 2010; Bruneel et al., 2011). Oxidation of soluble $\mathrm{Fe}(\mathrm{II})$ into relatively insoluble $\mathrm{Fe}(\mathrm{III})$ leads to over-saturation of water with respect to $\mathrm{Fe}(\mathrm{III})$-bearing minerals. In acidic sulfate-rich waters, iron sulfates and oxyhydroxides form, following the sequence jarosite $\left[\mathrm{KFe}_{3}\left(\mathrm{SO}_{4}\right)_{2}(\mathrm{OH})_{6}\right]$, schwertmannite $\left[\mathrm{Fe}_{8} \mathrm{O}_{8}(\mathrm{OH})_{6} \mathrm{SO}_{4}\right]$, ferrihydrite $\left[\mathrm{Fe}_{5}(\mathrm{OH})_{8} \cdot 4 \mathrm{H}_{2} \mathrm{O}\right]$, and goethite $[\alpha \mathrm{FeOOH}]$ with increasing pH (Bigham et al., 1996a,b; Foster et al., 1998; Savage et al., 2000; Burgos et al., 2012). These phases may be crystalline (jarosite, goethite) or poorly ordered (schwertmannite, ferrihydrite). Indeed, nanocrystalline or amorphous iron oxyhydroxides and hydroxysulfates are kinetically favored with respect to crystalline phases upon rapid $\mathrm{Fe}(\mathrm{II})$ oxidation because high oversaturation with respect to $\mathrm{Fe}$ (III)-bearing minerals leads to high nucleation rates. Therefore, these poorly ordered ferric minerals frequently occur as transient phases in AMD systems. They exhibit very high surface areas (several $100 \mathrm{~m}^{2} / \mathrm{g}$ ) and thus play a key role in the geochemical cycling of minor and trace elements, which sorb on their surfaces or are incorporated in their structures.

For instance, a number of laboratory studies have shown that $\mathrm{As}(\mathrm{V})$ sorbs onto the surface of minerals such as ferrihydrite (Pierce and Moore, 1982; Waychunas et al., 1993, 1995a; Raven et al., 1998) and goethite (Fendorf et al., 1997; Manning et al., 1998). Such sorption processes have also been found in EXAFS studies of mine tailings and AMD environments by Foster et al. (1998) and Savage et al. (2000). This latter study has shown that $\mathrm{As}(\mathrm{V})$ may be incorporated at low concentrations in jarosite $\left[\mathrm{KFe}_{3}\left(\mathrm{SO}_{4}\right)_{2}(\mathrm{OH})_{6}\right]$ where it substitutes for $\left(\mathrm{SO}_{4}\right)^{2-}$ oxoanions. Importantly, $\mathrm{As}(\mathrm{V})$ sorbs at high loadings onto schwertmannite $\left[\mathrm{Fe}_{8} \mathrm{O}_{8}(\mathrm{OH})_{6} \mathrm{SO}_{4}\right]$ (Burton et al., 2009), and this mineral has been identified as an $\mathrm{As}(\mathrm{V})$ scavenger in AMD systems (Fukushi et al., 2003) and has further been proposed as a water treatment sorbent in these environments (Carlson et al., 2002; Fukushi et al., 2004). In a comparison of AMD sediments with synthetic analogs using XRD, Carlson et al. (2002) showed that As(V) can also co-precipitate with ferric iron to form amorphous ferric arsenate with $\mathrm{As} / \mathrm{Fe}$ ratios as high as 0.8 , whereas schwertmannite forms at lower As/Fe ratios. In a previous EXAFS study of synthetic samples, Paktunc et al. (2008) proposed that the local structure of amorphous ferric arsenate consists of single chains of corner-sharing $\mathrm{FeO}_{6}$ octahedra with bridging $\mathrm{AsO}_{4}$ tetrahedra alternating along the chains, as in the structure of sulfate minerals such as butlerite, parabutlerite, and fibroferrite. An investigation of arsenate-rich Fe-precipitates from continental acidic hot-springs (Inskeep et al., 2004) also illustrated the strong ability of $\mathrm{As}(\mathrm{V})$ to coprecipitate with $\mathrm{Fe}(\mathrm{III})$ in acidic sulfate waters to form hydrated amorphous ferric arsenate phases. These studies have shown that $\mathrm{H}_{2} \mathrm{As}(\mathrm{V}) \mathrm{O}_{4}{ }^{-}$oxoanions retard or inhibit the formation of schwertmannite (Waychunas et al., 1995b; Carlson et al., 2002) or ferrihydrite (Paktunc et al., 2008) when the $\mathrm{As}(\mathrm{V}) / \mathrm{Fe}(\mathrm{III})$ molar ratio exceeds $\sim 0.25$ in the starting solution. However, the uniqueness of the local structure of amorphous ferric arsenate, especially the possibility of the existence of various local structures 
depending on formation conditions of the ferric arsenate is still under debate (Paktunc, 2010; Jiang et al., 2010).

In addition, the $\mathrm{As}(\mathrm{V})$ to schwertmannite binding modes are still poorly documented from direct structural analysis. XRD (Carlson et al., 2002) and EXAFS (Waychunas et al., $1995 \mathrm{~b})$ studies have suggested that $\mathrm{H}_{2} \mathrm{As}\left(\mathrm{V} \mathrm{O}_{4}{ }^{-}\right.$oxoanions strongly bind to $\mathrm{FeO}_{6}$ octahedra via inner sphere complexes upon precipitation of schwertmannite, which is thought to inhibit crystal growth and may explain the formation of an amorphous ferric arsenate at high $\mathrm{As} / \mathrm{Fe}$ ratio (Waychunas et al., 1995a; Paktunc et al., 2008). On the other hand, the significant displacement of sulfate ions upon sorption of arsenate oxoanions on schwertmannite has led to the suggestion that arsenate could substitute for sulfate, assuming an akaganeite-like structure for schwertmannite (Bigham et al., 1990; Burton et al., 2009; Fernandez-Martinez et al., 2010). In such a structure, sulfate ions are proposed to be mainly hydrogen bonded to the iron-oxyhydroxide network within the channels and at the particle surface (Majzlan and Myneni, 2005). There is less sulfate exchange for $\mathrm{H}_{3} \mathrm{As}(\mathrm{III}) \mathrm{O}_{3}$, which is known to sorb less efficiently than $\mathrm{H}_{2} \mathrm{As}(\mathrm{V}) \mathrm{O}_{4}{ }^{-}$on schwertmannite at acidic $\mathrm{pH}$ (Burton et al., 2009; Paikaray et al., 2011). Despite this existing knowledge concerning the reactivity of As(III) with respect to schwertmannite in the laboratory, the mechanisms of As(III) scavenging by schwertmannite in AMD systems is still poorly documented, although the more toxic $\mathrm{H}_{3} \mathrm{As}(\mathrm{III}) \mathrm{O}_{3}$ species may be the dominant dissolved arsenic species in acidic waters of AMD systems (Casiot et al., 2003; Morin et al., 2003; Morin and Calas, 2006), and hot springs (Inskeep et al., 2004). In addition, the possible influence of microbial activity and exopolymeric substances on the structure of As-bearing $\mathrm{Fe}$ minerals has been rarely investigated in AMD samples (Benzerara et al., 2008). For instance, a study by Egal et al. (2009) showed that the kinetics of bacterial $\mathrm{Fe}(\mathrm{II})$ oxidation can influence the nature of minerals forming in high As(III) AMD systems, with slow or fast oxidation rates leading to the formation of tooeleite $\left[\left(\mathrm{Fe}_{6}(-\right.\right.$ $\left.\left.\left.\mathrm{AsO}_{3}\right)_{4} \mathrm{SO}_{4}(\mathrm{OH})_{4} \cdot 4 \mathrm{H}_{2} \mathrm{O}\right)\right]$ or $\mathrm{As}(\mathrm{III})$-rich schwertmannite, respectively.

The main objective of the present study is to directly determine the molecular-level structure of poorly crystalline $\mathrm{As}(\mathrm{III})$ - and $\mathrm{As}(\mathrm{V})$-bearing $\mathrm{Fe}$ oxyhydroxysulfate minerals from the Carnoulès AMD system, France, which exhibits exceptionally high As(III) concentrations. Powder X-ray diffraction (XRD) and extended X-ray absorption fine structure (EXAFS) spectroscopy were used to compare the local As structural environments in these field samples with those of synthetic analogs prepared via biotic or abiotic pathways, with $\mathrm{As} / \mathrm{Fe}$ ratios ranging from those in nanocrystalline schwertmannite to those in amorphous ferric arsenate compounds.

\section{MATERIALS AND METHODS}

\subsection{AMD samples}

Hydrated and loosely packed sediments were sampled in the upstream section of the acidic Reigous creek ( $\mathrm{pH} 3-4.5$ ) (Carnoulès AMD, France), which exhibits exceptionally high concentrations of dissolved $\mathrm{As}(\mathrm{III})$ and $\mathrm{As}(\mathrm{V})$ (up to $250 \mathrm{mg} / \mathrm{L}$ dissolved total As) and of dissolved iron and sulfate ( $\sim 0.5-1 \mathrm{~g} / \mathrm{L}$ and $\sim 1-3 \mathrm{~g} / \mathrm{L}$, respectively) (Casiot et al., 2003, 2005; Egal et al., 2010). Samples were air dried for $24 \mathrm{~h}$ and stored in a dry atmosphere before spectroscopic analysis. Sample 'Sed S32F00' was sampled $32 \mathrm{~m}$ downstream from the acidic spring and consists of amorphous $\mathrm{Fe}(\mathrm{III})-\mathrm{As}(\mathrm{V})$ oxyhydroxysulfate with an As/Fe molar ratio of 0.63 and with an As(III)/AsTotal ratio of 0.05 as determined by electron microprobe analysis (EMPA) and $\mathrm{X}$-ray absorption near edge structure (XANES) spectroscopy, respectively (Fig. S1; Morin et al., 2003). Sample 'Sed arch0503' was sampled $\sim 200 \mathrm{~m}$ downstream from the acidic spring and consists of poorly ordered oxyhydroxysulfate with an As/Fe molar ratio of 0.45 and an $\mathrm{As}$ (III)/AsTotal ratio of 0.23 , as determined using the same methods (Lebrun, 2004). Sample 'Sed foyer0303' was sampled $\sim 1000$ m downstream from the acidic spring and consists of poorly ordered schwertmannite with an $\mathrm{As} / \mathrm{Fe}$ molar ratio of 0.25 and an $\mathrm{As}$ (III)/AsTotal ratio of 0.46 , as determined using the same methods (Lebrun, 2004).

\subsection{Biogenic laboratory samples}

Model compound samples were prepared via microbial incubation of sterilized water from the Carnoulès AMD water with autochthonous bacterial strains: Thiomonas sp. (Tm B2 and Tm B3 strains; Morin et al., 2003) and A. ferrooxidans (Af CC1 strain; Duquesne et al., 2003; Egal et al., 2009). Incubations with strain $T m$ B2 or $T m$ B3 yielded amorphous $\mathrm{As}(\mathrm{V})-\mathrm{Fe}(\mathrm{III})$ oxyhydroxysulfate as the single solid product, owing to the ability of these strains to catalyze the oxidation of $\mathrm{As}(\mathrm{III})$ to $\mathrm{As}(\mathrm{V})$ at acidic $\mathrm{pH}$, with $\mathrm{Fe}(\mathrm{II})$ being slowly oxidized abiotically by dissolved $\mathrm{O}_{2}$ over the 1 week experiment (Morin et al., 2003; Casiot et al., 2003). Samples obtained after incubation by strains $T m$ B2 or $T m$ B3 are characterized by As/Fe molar ratios of 0.63 and 0.8 , respectively, and do not contain $\mathrm{As}(\mathrm{III})$ as determined by EMPA and XANES spectroscopy (Fig. S1; Morin et al., 2003). In contrast, incubation with strain $A f \mathrm{CC} 1$ for 5 days yields pure As(III)-rich schwertmannite due to the ability of this strain to catalyze Fe(II) to $\mathrm{Fe}(\mathrm{III})$ oxidation without significant abiotic oxidation of $\mathrm{As}(\mathrm{III})$ to $\mathrm{As}(\mathrm{V})$ (Duquesne et al., 2003; Egal et al., 2009). This sample exhibits an As/Fe molar ratio of 0.19 and does not contain $\mathrm{As}(\mathrm{V})$ as determined by EMPA and XANES spectroscopy (Egal et al., 2009).

\subsection{Synthetic abiotic analogs}

Abiotic model compounds were prepared according to the schwertmannite synthesis protocol from Loan et al. (2004), which was modified by adding various amounts of dissolved As(III) or As(V) in the starting solutions. This protocol relies on hydrolysis of ferric iron in acidic sulfate water at $\mathrm{pH} 3$, at a temperature of $80{ }^{\circ} \mathrm{C}$. This protocol was chosen for As-coprecipitation samples instead of the one we used for pure schwermannite and schwertmannite sorption samples (see next paragraph) because of the absence of an $\mathrm{H}_{2} \mathrm{O}_{2}$ oxidation step, in order to avoid As(III) 
oxidation. The protocol was modified by mixing appropriate volumes of $100 \mathrm{mM} \mathrm{NaAsO}$ or $\mathrm{Na}_{2} \mathrm{HAsO}_{4}$ stock solutions with $100 \mathrm{~mL}$ of a $16 \mathrm{mM}$ ferric sulfate stock solution, in order to obtain $\mathrm{As}(\mathrm{III}) / \mathrm{Fe}(\mathrm{III})$ or $\mathrm{As}(\mathrm{V}) / \mathrm{Fe}(\mathrm{III})$ dissolved molar ratios of $0,0.025,0.05,0.1,0.2,0.4,0.6$, and 0.8 . The volume of the mixture was increased to $250 \mathrm{~mL}$ by adding deionized water to polypropylene flasks containing the mixture, and the $\mathrm{pH}$ was adjusted to 3 using $\mathrm{H}_{2} \mathrm{SO}_{4}$, thus giving a starting dissolved $\mathrm{Fe}(\mathrm{III})$ concentration of $6.4 \mathrm{mM}$. Initial dissolved As concentrations were thus 0 , $0.16,0.32,0.64,1.28,2.56,3.85$, and $5.12 \mathrm{mM}$. Each aliquot was then heated to $80^{\circ} \mathrm{C}$ for one hour in closed flasks under magnetic stirring. Suspensions were then cooled in icewater, centrifuged at $10,000 \mathrm{~g}$, and washed two times in deionized water. In order to preserve the As(III) oxidation state, all experiments with As(III) were conducted with degassed deionized water. The solids were then dried under vacuum and stored in a dry atmosphere before spectroscopic analysis. Supernatants were analyzed for dissolved As and $\mathrm{Fe}$ concentrations after $0.2 \mu \mathrm{m}$ filtration using flame Atomic Absorption Spectroscopy (Solaar S, Thermo electron corporation). Chemical compositions of the solids were determined by averaging 15 EDXS analyses per sample. X-ray emission spectra were collected on thin powder samples deposited on carbon tape using a Bruker Si-drift detector mounted in a Zeiss Scanning Electron Microscope operating at $15 \mathrm{kV}$ with a $60 \mu \mathrm{m}$ diaphragm. Hematite and scorodite were used as standards for semi-quantitative analyses with the Esprit software (http://www.bruker-axs.com/ esprit_software.html). The solid As/Fe molar ratio values estimated with this method were consistent with those determined from the supernatant analyses. Solid As/Fe values and corresponding standard deviations were then estimated by averaging these two sets of values.

In addition, model compounds consisting of arsenic sorbed on schwertmannite were prepared at $\mathrm{pH} 3$ by reacting for $24 \mathrm{~h} 550 \mu \mathrm{M}$ solutions of $\mathrm{Na}_{2} \mathrm{HAsO}_{4}$ or $\mathrm{NaAsO}_{2}$ with $1 \mathrm{~g} / \mathrm{L}$ of schwertmannite prepared according to the protocol of Barham (1997). For this synthesis protocol, $100 \mathrm{~mL}$ of a $0.1 \mathrm{M}$ ferrous sulfate solution adjusted to $\mathrm{pH}$ 2.5 using $\mathrm{H}_{2} \mathrm{SO}_{4}$ was oxidized by an excess of $\mathrm{H}_{2} \mathrm{O}_{2}$. The schwertmannite precipitate was washed and air-dried before resuspension in deionized water for the sorption experiment. After $24 \mathrm{~h}$ of interaction of the schwertmannite precipitate with aqueous arsenic, the sorption samples were centrifuged and vacuum dried, and then stored under a dry atmosphere before spectroscopic analyses. Final As/Fe ratios in the solids were 0.04 and 0.09 for the As(III)- and As(V)-schwertmannite sorption samples, respectively. XANES analysis indicated that the oxidation state of arsenic was fully preserved during the sorption process (Lebrun, 2004).

\subsection{XRD and EXAFS analyses}

X-ray powder diffraction patterns of AMD samples and of biogenic model compounds were recorded using a PW1710 Philips diffractometer equipped with a backmounted graphite monochromator, and using $\mathrm{Co} \mathrm{K} \alpha$ radiation. Data were recorded in step-scan mode using $0.04^{\circ} 2 \theta$ steps and a counting time of $6-12 \mathrm{~h}$ per sample. XRD patterns of the synthetic model compounds were recorded using an Xpert pro PanAlytical diffractometer equipped with an XCelerator linear detector and filtering the Co $\mathrm{K} \beta$ radiation using a $\mathrm{Fe}$ filter. Data were recorded in continuous mode with a resulting $2 \theta$ step of $0.05^{\circ}$ and counting for 3 to $6 \mathrm{~h}$ per sample over the $10-100^{\circ} 2 \theta$ range. Bragg peaks from the aluminum sample holder were removed from the data for samples that were too thin due to a low amount of powder.

EXAFS spectroscopy data were recorded at a temperature below $20 \mathrm{~K}$ in a liquid helium cryostat in order to maximize second-neighbor contributions in the EXAFS of the poorly crystalline samples studied. All Fe K-edge data were recorded in transmission detection mode using a $\mathrm{Si}(111)$ double-crystal monochromator at the BM29 beamline (ESRF), except for samples Sed S32F00, Tm B2, and Tm B3, that were analyzed at the D44 beamline (LURE) using a similar setup. Most of the As K-edge EXAFS data were recorded in transmission mode at the XAFS beamline (ELETTRA) using a $\mathrm{Si}(1111)$ double-crystal monochromator, except for the $A f \mathrm{CC} 1$ sample that was analyzed at the 11-2 beamline (SSRL) using a $\mathrm{Si}(220)$ double-crystal monochromator. Iron K-edge EXAFS data of sample Sed arch0503 were recorded in transmission mode at the FAME beamline (ESRF) using a Si(220) double-crystal monochromator. Arsenic K-edge EXAFS data of the two arsenic sorption samples and of sample Sed arch0503 were recorded in fluorescence detection mode using a Canberra Ge 30 elements detector at the FAME beamline (ESRF), using a $\mathrm{Si}(220)$ double-crystal monochromator.

EXAFS spectra were extracted from the raw fluorescence data using the XAFS program (Winterer, 1996) after averaging and normalization using the Athena Program (Ravel and Newville, 2005) or the SixPack Program (Webb, 2005) for SSRL data. Radial distribution functions (RDF) were obtained by Fourier transforming the $k^{3} \chi(k)$ EXAFS functions using a Kaiser-Bessel window, with a Bessel weight of 2.5. Least-squares fitting of the unfiltered $k^{3} \chi(k)$ functions was performed with the plane-wave formalism, with a $\mathrm{S}_{0}{ }^{2}$ value set to 1 , using a Levenberg-Marquard minimization algorithm. Theoretical phase-shift and amplitude functions employed in this fitting procedure were calculated with the curved-wave formalism using the ab initio FEFF8 code (Ankudinov et al., 1998). As-O and As-Fe phase-shift and amplitude functions were extracted from the scorodite (Hawthorne, 1976) and tooeleite (Morin et al., 2007) crystal structures. For faster calculations, the threshold energy was calculated without using the self-consistent potential option in FEFF8, which explains the high $\Delta E_{0}$ values observed in our fits of As K-edge EXAFS data. The fit quality was estimated using the classical reduced $\chi^{2}$ (see Table 1 ).

\section{RESULTS AND DISCUSSION}

\subsection{Chemistry and mineralogy of the laboratory and field samples}

The chemical compositions of the solids and supernatants for the synthetic samples obtained from precipitation 
Table 1

Results of shell-by-shell fitting of unfiltered EXAFS data at the Fe K-edge for the As(III) samples studied. $R(\AA)$ : interatomic distances; $N$ : number of neighbors; $\sigma(\AA)$ : Debye Waller factor; $\Delta E$ $(\mathrm{eV})$ : difference between the experimentally determined threshold energy and the FEFF8-calculated threshold energy, without using the self-consistent potential calculation; Standard deviations of these fit parameters are $0.02 \AA, \pm 30 \%, 0.01 \AA$, and $2 \mathrm{eV}$, respectively $\chi_{F T}^{2}$ is a goodness of fit estimate $\chi_{F T}^{2}=N_{\text {ind }} /\left[\left(N_{\text {ind }}-p\right) n\right] \Sigma_{1}^{n}\left(\|F T\|_{\text {exp }}-\|F T\|_{\text {calci }}\right)^{2}$ with $\left.N_{\text {ind }}=(2 \Delta k \Delta R) / \pi\right)$, the number of independent parameters, $p$ the number of free fit parameters, $n$ the number of data points fitted, and $\|F T\|_{\text {exp }}$ and $\|F T\|_{\text {calc }}$ the experimental and theoretical Fourier transform magnitudes within the 0-8 A R-range. Note. ${ }^{\mathrm{v}} \mathrm{As}(\mathrm{V}) / \mathrm{AsT}$ tal if greater than 0.00; "fixed $N$ value. As/Fe and S/Fe molar ratio of the solid samples are reported. $\mathrm{nd}$ : not deter

\begin{tabular}{|c|c|c|c|c|c|c|c|c|c|c|c|c|c|}
\hline Sample & Origin & $\mathrm{As} / \mathrm{Fe} \mathrm{mol} / \mathrm{mol}$ & $\mathrm{S} / \mathrm{Fe} \mathrm{mol} / \mathrm{mol}$ & $R(\AA)$ & $N$ & $\sigma(\AA)$ & $R(\AA)$ & $N$ & $R(\AA)$ & $N$ & $\sigma(\AA)$ & $\chi_{F T}^{2}$ & $\Delta E_{0}(\mathrm{eV})$ \\
\hline \multirow[t]{4}{*}{ As free } & Abiotic lab sample & 0.00 & n.d. & 1.94 & $3.15 \mathrm{FeO}$ & 0.08 & 3.03 & $1.2 \mathrm{FeFe}$ & 5.53 & $0.8 \mathrm{FeFe}$ & 0.06 & 0.02 & -2 \\
\hline & & & & 2.07 & $1.93 \mathrm{FeO}$ & & 3.31 & $0.7 \mathrm{FeFe}$ & 6.03 & $0.6 \mathrm{FeFeFeFe}$ & & & \\
\hline & & & & & & & 3.40 & $24.0 \mathrm{FeOO}^{*}$ & & & & & \\
\hline & & & & & & & 3.42 & $1.1 \mathrm{FeFe}$ & & & & & \\
\hline \multirow[t]{4}{*}{ As3_0.1 } & Abiotic lab sample & $0.06(1)$ & $0.19(4)$ & 1.93 & $2.55 \mathrm{FeO}$ & 0.08 & 3.03 & $1.2 \mathrm{FeFe}$ & 5.50 & $0.8 \mathrm{FeFe}$ & 0.07 & 0.01 & -2 \\
\hline & & & & 2.05 & $2.25 \mathrm{FeO}$ & & 3.30 & $0.6 \mathrm{FeFe}$ & 6.02 & $0.6 \mathrm{FeFeFeFe}$ & & & \\
\hline & & & & & & & 3.42 & $1.2 \mathrm{FeFe}$ & & & & & \\
\hline & & & & & & & 3.39 & $24.0 \mathrm{FeOO}^{*}$ & & & & & \\
\hline \multirow[t]{4}{*}{ As3_0.2 } & Abiotic lab sample & $0.10(1)$ & $0.22(1)$ & 1.91 & $2.15 \mathrm{FeO}$ & 0.07 & 3.02 & $1.1 \mathrm{FeFe}$ & 5.51 & $0.7 \mathrm{FeFe}$ & 0.07 & 0.02 & -3 \\
\hline & & & & 2.04 & $2.45 \mathrm{FeO}$ & & 3.33 & $0.7 \mathrm{FeFe}$ & 6.02 & $0.5 \mathrm{FeFeFeFe}$ & & & \\
\hline & & & & & & & 3.41 & $24.0 \mathrm{FeOO}^{*}$ & & & & & \\
\hline & & & & & & & 3.44 & $0.9 \mathrm{FeFe}$ & & & & & \\
\hline \multirow[t]{4}{*}{ As3_0.4 } & Abiotic lab sample & $0.16(2)$ & $0.24(1)$ & 1.93 & $2.30 \mathrm{FeO}$ & 0.07 & 3.04 & $1.2 \mathrm{FeFe}$ & 5.55 & $1.0 \mathrm{FeFe}$ & 0.07 & 0.03 & -2 \\
\hline & & & & 2.06 & $2.25 \mathrm{FeO}$ & & 3.31 & $0.8 \mathrm{FeFe}$ & 6.03 & $0.7 \mathrm{FeFeFeFe}$ & & & \\
\hline & & & & & & & 3.37 & $24.0 \mathrm{FeOO}^{*}$ & & & & & \\
\hline & & & & & & & 3.43 & $1.3 \mathrm{FeFe}$ & & & & & \\
\hline \multirow[t]{3}{*}{ As3_0.6 } & Abiotic lab sample & $0.21(2)$ & $0.22(1)$ & 1.93 & $2.55 \mathrm{FeO}$ & 0.08 & 3.03 & $1.3 \mathrm{FeFe}$ & 5.52 & $0.6 \mathrm{FeFe}$ & 0.08 & 0.02 & -2 \\
\hline & & & & 2.05 & $2.45 \mathrm{FeO}$ & & 3.41 & $1.2 \mathrm{FeFe}$ & 6.01 & $0.6 \mathrm{FeFeFeFe}$ & & & \\
\hline & & & & & & & 3.46 & $24.0 \mathrm{FeOO}^{*}$ & & & & & \\
\hline \multirow[t]{4}{*}{ Af $\mathrm{CCl}$} & $\begin{array}{l}\text { Biogenic lab } \\
\text { sample }\end{array}$ & $0.19(1)$ & n.d. & 1.92 & $2.30 \mathrm{FeO}$ & 0.07 & 3.04 & 2.0 FeFe & 5.48 & $0.6 \mathrm{FeFe}$ & 0.09 & 0.03 & -2 \\
\hline & & $0.05^{\mathrm{V}}$ & & 2.04 & $2.80 \mathrm{FeO}$ & & 3.26 & $1.5 \mathrm{FeFe}$ & 6.03 & $0.7 \mathrm{FeFeFeFe}$ & & & \\
\hline & & & & & & & 3.34 & $24.0 \mathrm{FeOO}^{*}$ & & & & & \\
\hline & & & & & & & 3.42 & $1.9 \mathrm{FeFe}$ & & & & & \\
\hline \multirow{3}{*}{ Sed foyer0303 } & AMD sample & & $0.20(1)$ & 1.94 & $2.55 \mathrm{FeO}$ & 0.08 & 3.03 & $1.0 \mathrm{FeFe}$ & 5.51 & & 0.08 & 0.01 & -2 \\
\hline & & $0.47^{\mathrm{V}}$ & & 2.05 & $2.35 \mathrm{FeO}$ & & 3.43 & $24.0 \mathrm{FeOO}^{*}$ & 6.03 & $0.4 \mathrm{FeFeFeFe}$ & & & \\
\hline & & & & & & & 3.39 & $0.8 \mathrm{FeFe}$ & & & & & \\
\hline
\end{tabular}



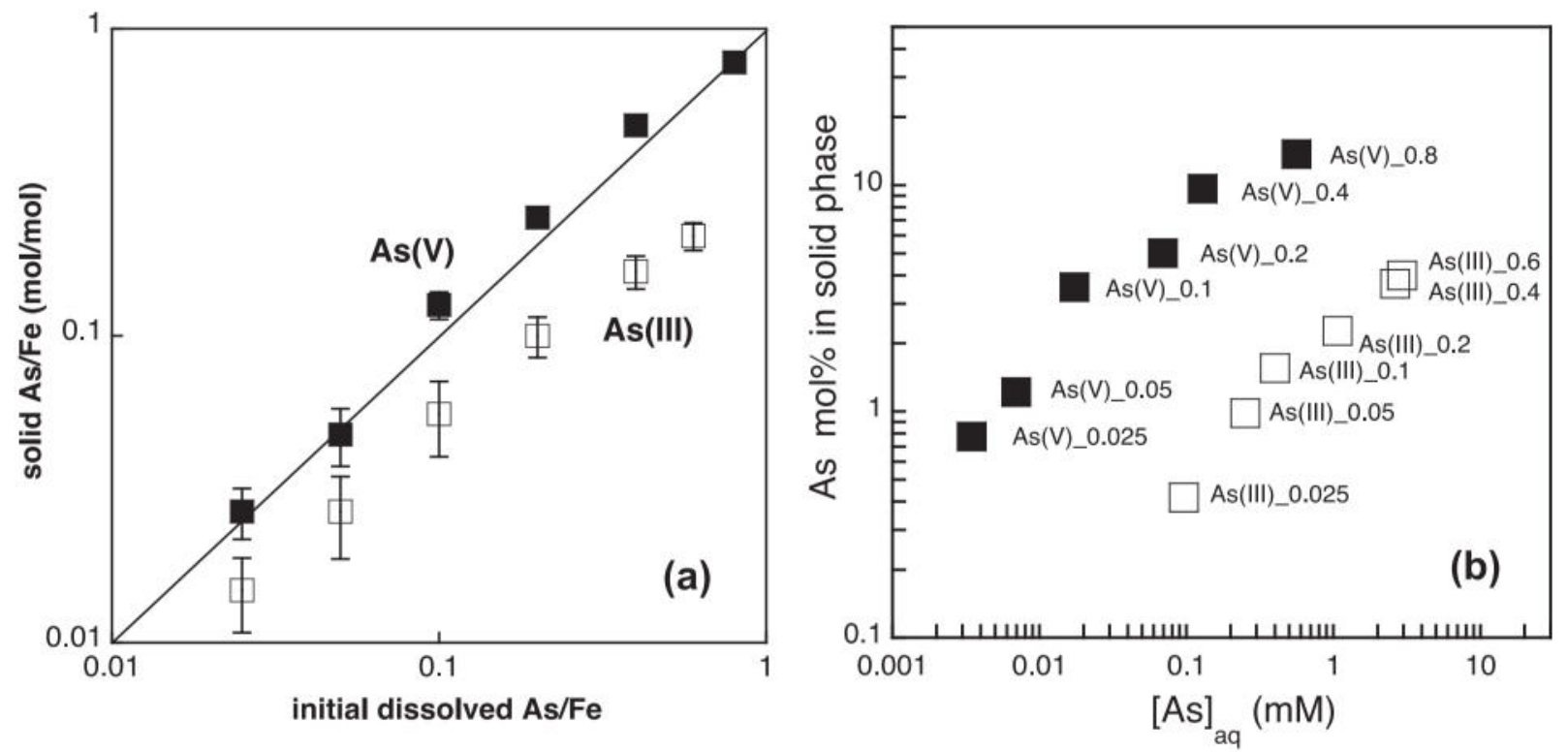

Fig. 1. Chemical composition of the solids (centrifuged) and supernatants (filtered through $<0.2 \mu \mathrm{m}$ cellulose filters) for the series of abiotic synthetic samples studied. (a) As/Fe molar ratio in the solid phase as a function of the initial $\mathrm{As} / \mathrm{Fe}$ ratio in the aqueous phase. (b) As concentration in the solid phase as a function of the final As concentration in solution. Sample labels are recalled on the right side of each point.

of schwertmannite at $\mathrm{pH} 3$ in the presence of increasing concentrations of $\mathrm{As}(\mathrm{III})$ or $\mathrm{As}(\mathrm{V})$ in the starting solution are plotted in Figs. 1 and S2. These results indicate a high uptake of $\mathrm{As}(\mathrm{V})$ in or on the solid phase $(89-98 \%$ of the initial dissolved As), whereas only $20-40 \%$ uptake was observed for As(III) (Fig. S2a). The As/Fe ratio in the solid phase is systematically lower than the initial $\mathrm{As} / \mathrm{Fe}$ in the case of $\mathrm{As}(\mathrm{III})$, whereas it is close to the initial ratio in the case of $\mathrm{As}(\mathrm{V})$ (Fig. 1a). This lower affinity of $\mathrm{As}(\mathrm{III})$ for the solid phase is also well illustrated by the $\sim 10$ times higher final concentrations of dissolved As(III) compared to $\mathrm{As}(\mathrm{V})$, for similar As concentration in the solid (Fig. 1b).

XRD patterns of the $\mathrm{As}(\mathrm{III})$ and $\mathrm{As}(\mathrm{V})$-rich samples are displayed in Figs. 2 and 3, respectively, and their corresponding $\mathrm{As} / \mathrm{Fe}$ ratios in the solid phases are reported in Tables 1 and 2 for As(III) samples, and in Tables 3 and 4 for $\mathrm{As}(\mathrm{V})$ samples. Fig. 2 shows that all $\mathrm{As}(\mathrm{III})$ samples studied, including the field sample Sed foyer0303 and the biotic and abiotic analogs, consist of schwertmannite, based on comparison with a synthetic As-free schwertmannite, which matches the pattern indexed using the crystal structure recently proposed by Fernandez-Martinez et al. (2010). However, line broadening is observed when increasing the As/Fe ratio in the solid, which may be related either to a decrease in size of the schwertmannite crystallites and/ or to the occurrence of structural defects. Assuming that the broadening would be only due to the decrease of the mean coherent domain size (MCD), application of the Scherrer formula to the observed line width indicates that the MCD size along the [221] direction (sharpest Bragg peak) would remain about constant at $\sim 7.5 \pm 0.5 \mathrm{~nm}$ for all samples, whereas the MCD [301] value decreases from $5.2 \pm 0.5$ for the As-free sample to $4.1 \pm 0.5 \mathrm{~nm}$ for the As-rich Sed foyer0303 AMD sample. Assuming that part of the broadening might be due to structural defects, XRD results suggest that the MCD values of schwertmannite vary less than $25 \%$ within the range of $\mathrm{As}(\mathrm{III}) / \mathrm{Fe}$ ratios investigated. The $\mathrm{As}(\mathrm{V})$ samples consist of schwertmannite up to an initial $\mathrm{As} / \mathrm{Fe}$ molar ratio of 0.1, without significant line broadening. However, for higher $\mathrm{As} / \mathrm{Fe}$ ratios, the XRD patterns indicate a mixture with an amorphous phase, which becomes dominant at an initial As/Fe ratio of 0.2 , and fully replaces schwertmannite above this ratio. This trend is observed for both AMD samples and model compounds, both biotic and abiotic. The XRD pattern of this amorphous phase as well as its chemical composition are consistent with those of amorphous $\mathrm{As}(\mathrm{V})-\mathrm{Fe}(\mathrm{III})$ oxyhydroxysulfate, also referred to as ferric arsenate (Paktunc et al., 2008). EXAFS spectroscopy at the As and Fe Kedges were used to determine the mode of As associations with schwertmannite and ferric arsenate mineral phases.

\subsection{Molecular-level structure of the As(III) samples}

EXAFS data at the Fe K-edge of the As(III) samples are displayed in Fig. 4. Results of shell-by-shell fits of these data are reported in Table 1. The field sediment sample 'Sed foyer0303' is compared with a biogenic As(III)-rich schwertmannite ' $A f \mathrm{CCl}^{\prime}$ ', prepared by inoculating sterilized AMD water with the model $A$. ferrooxidans strain CC1 (Figs. S3 and S4), and with synthetic schwertmannite samples prepared by aqueous precipitation in the presence of dissolved As(III) (Figs. S5 and S6). The similarity of the EXAFS spectra at the $\mathrm{Fe} \mathrm{K}$-edge of all $\mathrm{As}(\mathrm{III})$-rich samples with the spectrum of As-free schwertmannite indicates that they all have a schwertmannite-like local structure (Table 1), in agreement with XRD data (Fig. 2). The local environment around $\mathrm{Fe}$ in schwertmannite is 


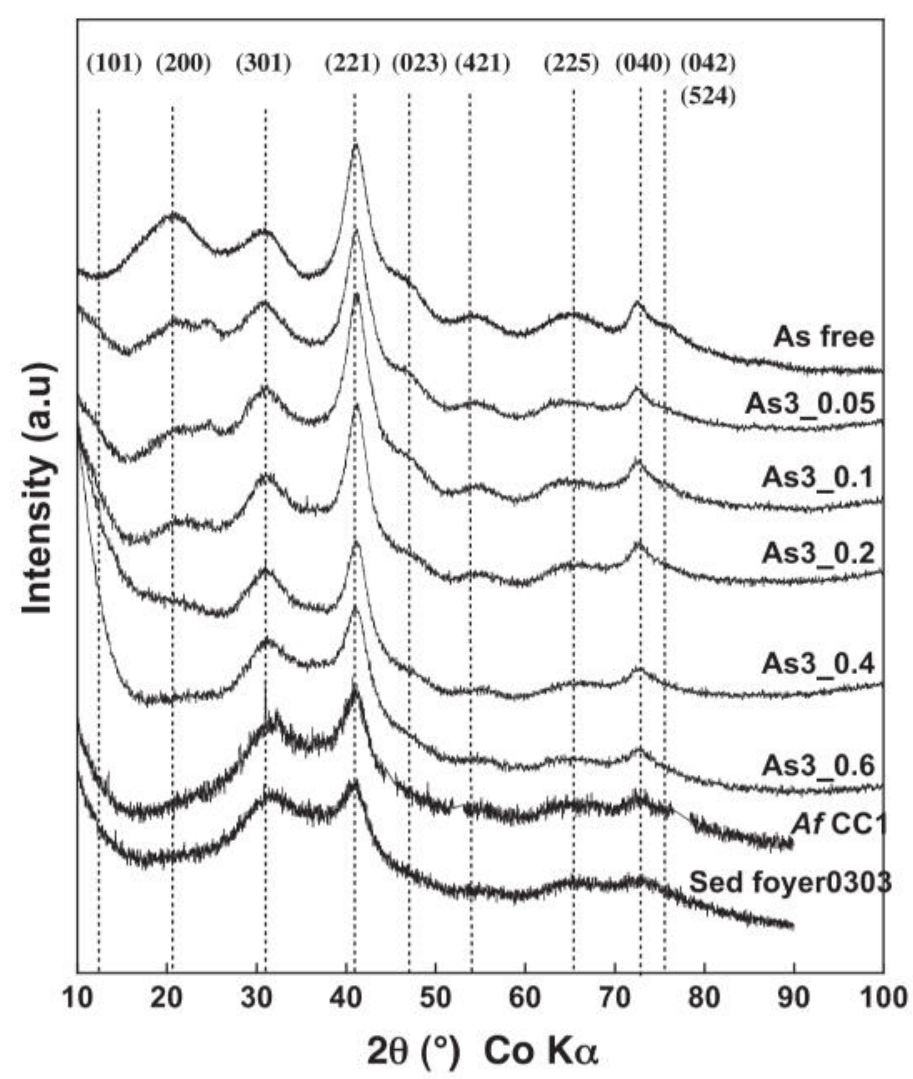

Fig. 2. Powder XRD patterns of the As(III) samples studied. All samples exhibit a schwertmannite-like pattern whatever the As/Fe molar ratio is in the solid phase. However, progressive broadening of the schwermannite Bragg peaks with increasing As loading indicate either a decrease in crystallite size or a defective structure, or both. Peaks from the Al sample holder have been subtracted from the pattern of sample Af CC1. Peak indexes refer to the monoclinic cell proposed by Fernandez-Martinez et al. (2010). Corresponding As/Fe ratios in the solid phases are reported in Tables 1 and 2 .

characterized by three types of $\mathrm{Fe}-\mathrm{Fe}$ distances at 3.0, 3.3, and $3.45 \AA$, in agreement with the crystal structure of goethite (Forsyth et al., 1968), or akaganeite (Post et al., 2003), both of which are characterized by double chains of edgesharing $\mathrm{Fe}(\mathrm{O}, \mathrm{OH})_{6}$ octahedra ( $\mathrm{Fe}-\mathrm{Fe}$ distances of 3.0 and $3.3 \AA$ ) connected by double corner sharing linkage ( $\mathrm{Fe}-\mathrm{Fe}$ distance of 3.4-3.5 $⿱$ ) (e.g., Maillot et al., 2011 and references therein). In addition, longer distance $\mathrm{Fe}-\mathrm{Fe}$ paths $(5.5 \AA)$ and multiple scattering $\mathrm{Fe}-\mathrm{Fe}-\mathrm{Fe}-\mathrm{Fe}$ paths ( $6.0 \AA$ ) observed in our EXAFS data for schwertmannite are also consistent with these structures (Fig. S7), the latter MS paths being consistent with the alignment of $\mathrm{Fe}(\mathrm{O}, \mathrm{OH})_{6}$ octahedra forming double-chains along the $b$ axis in the akaganeite and goethite structures. Although the observed $\mathrm{Fe}-\mathrm{Fe}$ distances are consistent with the goethite-akaganeite local structure, the number of observed Fe second neighbors (Table 1) is about equal to or less than half that expected from the bulk crystal structure of akaganeite, i.e., $N=2,2$, and 4 for the Fe neighbors at distances of 3.0,3.3, and $3.45 \AA$, respectively. This discrepancy could be explained by destructive interferences between the EXAFS signals from the $\mathrm{Fe}-\mathrm{Fe}$ pairs at 3.3 and $3.45 \AA$ (Maillot et al., 2011). It could also be related to the nanometer size of the schwertmannite crystallites $(4-8 \mathrm{~nm})$, for which the surface $\mathrm{Fe}$ atoms are expected to have 10-20\% less neighbors than in the bulk structure (Maillot et al., 2011). Alternatively, this discrepancy could be due to the occurrence of a significant amount of structural defects, in agreement with the XRD-PDF study of the schwertmannite structure performed by Fernandez-Martinez et al. (2010). Comparison of the Fe K-edge EXAFS results obtained for the series of As(III)-bearing schwertmannite samples in the present study indicate that the presence of As(III) during the precipitation of schwertmannite does not lead to major changes in the schwertmannite local structure (Table 1, Fig. 4). However, the intensity of the second-neighbor peak in the FT of the Fe K-EXAFS spectra decreases significantly with increasing the $\mathrm{As}(\mathrm{III}) / \mathrm{Fe}$ ratio in the solid (Fig. 4). This decrease is, however, better modeled by an increase of the Debye-Waller parameter (from 0.06 to 0.08 $0.09 \AA$ ) than by a net decrease in the number of $\mathrm{Fe}$ second neighbors (Table 1). Accordingly, the 3.3 and $3.4 \AA \mathrm{Fe}-\mathrm{Fe}$ paths could not be resolved in the EXAFS spectra of samples As3_0.6 and Sed foyer0303, with $\mathrm{As}(\mathrm{III}) / \mathrm{Fe}>0.16$ in the solid (Table 1). These results suggest that the presence of $\mathrm{As}$ (III) during schwertmannite precipitation leads to an increase in structural disorder rather than to a significant decrease in crystallite size, which would be consistent with the moderate change in crystallite size estimated from $\mathrm{XRD}$, as discussed above. 


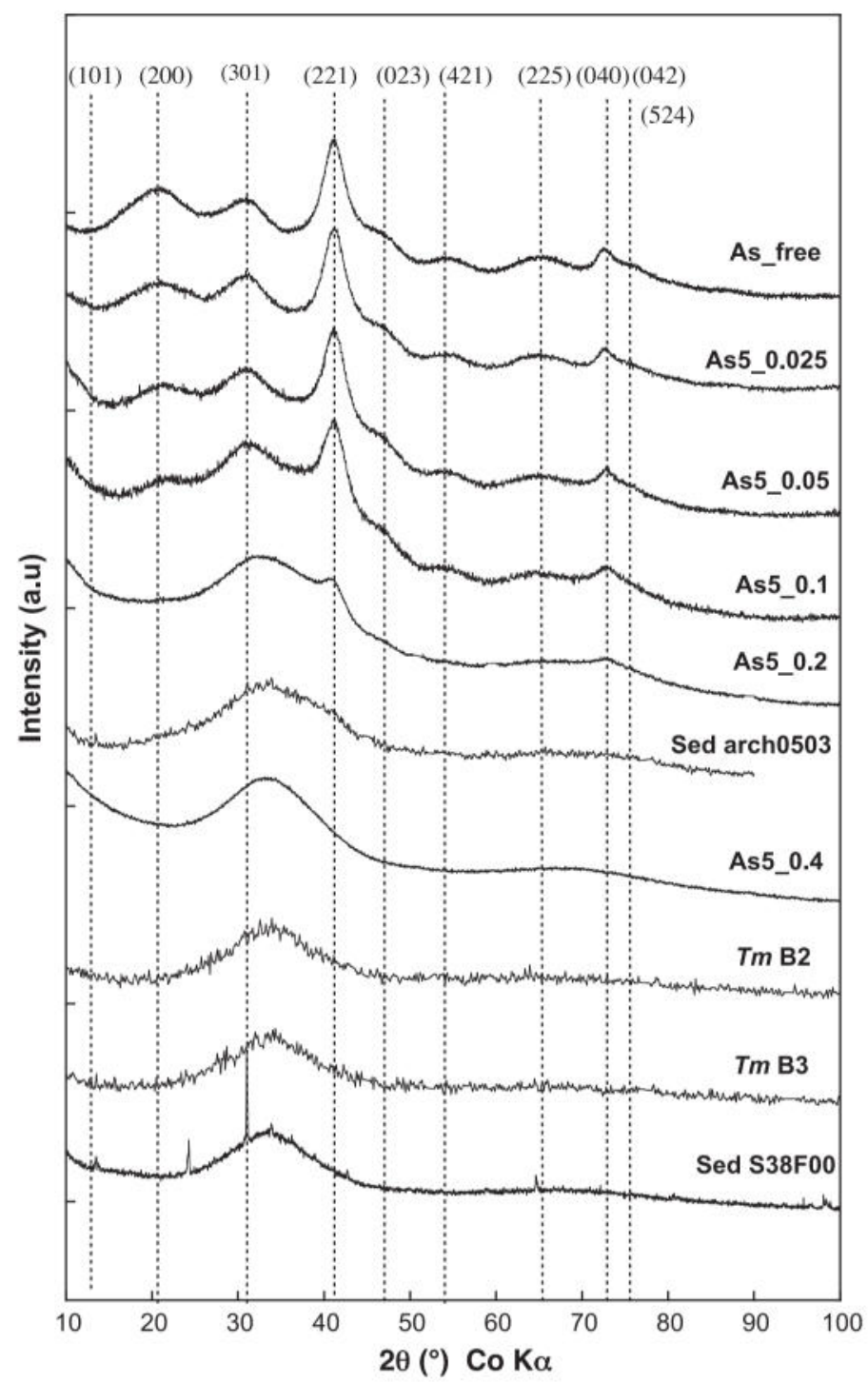

Fig. 3. Powder XRD patterns of the As(V) samples studied. Field samples from the Carnoulès AMD are compared with biogenic samples obtained after inoculating Thiomonas sp. strains B2 or B3 in sterilized AMD water, and with synthetic schwertmannite precipitated from ferric sulfate solution at $\mathrm{pH} 3$ in the presence of various concentrations of dissolved arsenate. Below As/Fe molar ratio of 0.2 in the solid phase, the products consist essentially of schwertmannite. The gradual broadening of Bragg peaks with increasing As/Fe ratio may be related to a decrease in crystallite size or to a defective structure, or both. Above As/Fe ratio of 0.2 in the solid phase, an amorphous ferric arsenate phase starts to form in mixture with schwertmannite and further dominates at high As/Fe ratio. The field sample contains minor amounts of quartz and mica. Peak indexes refer to the monoclinic cell proposed by Fernandez-Martinez et al. (2010). Corresponding As/Fe ratios in the solid phases are reported in Tables 3 and 4.

EXAFS data at the As K-edge for the As(III)-samples are displayed in Fig. 5. The first coordination shell around arsenic was fit by $3.0 \pm 0.5$ oxygen atoms at a distance of $1.79 \pm 0.02 \AA$ (Table 2), which is consistent with the known geometry of the $\mathrm{As}(\mathrm{III}) \mathrm{O}_{3}$ pyramid (e.g., Morin et al. 2007 and references therein). EXAFS data for the AMD sample Sed foyer 0303 were not analyzed using the present shell-byshell procedure because this sample contains a high amount $(47 \%)$ of $\mathrm{As}(\mathrm{V})$. For all the other $\mathrm{As}(\mathrm{III})$-containing samples, the second-neighbor contribution to the EXAFS is weak, suggesting that $\mathrm{As}(\mathrm{III})$ is mainly adsorbed at the surface of the schwertmannite particles rather than substituted for $\mathrm{Fe}(\mathrm{III})$ in the structure. These second-neighbor contributions are well fit by a combination of two distinct AsFe paths at distances of 2.9 and $3.4 \AA$ in variable proportions, depending both on the sample origin and the $\mathrm{As}(\mathrm{III}) / \mathrm{Fe}$ ratio (Table 2; Figs. S8 and S9). Multiple-scattering As- $-\mathrm{O}-\mathrm{O}$ paths within the $\mathrm{AsO}_{3}$ pyramid with a fixed multiplicity were systematically included in the fit in order to improve the reliability of the results (Table 2; Ona-Nguema et al., 2005). The contribution from the As-Fe path at $3.4 \AA$ is systematically larger than that at $2.9 \AA$, with a ratio $N_{3.4} / N_{2.9}$ ranging between 3 and 6 (Table 2). Interestingly, this ratio is maximum for the sorption sample $\left(N_{3.4}\right)$ 
Table 2

Results of shell-by-shell fitting of unfiltered EXAFS data at the As K-edge for the As(III) samples studied. $R(\AA)$ : interatomic distance; $N$ : number of neighbors; $\sigma(\AA)$ : Debye Waller factor; $\Delta E_{0}$ $(\mathrm{eV})$ : difference between the experimentally determined threshold energy and the FEFF8-calculated threshold energy, without using the self-consistent potential calculation; Standard deviations of these fit parameters are $0.02 \AA, \pm 15 \%$ and $\pm 30 \%$ for first and second neighbors respectively, $0.01 \AA$, and $2 \mathrm{eV}$, respectively $\chi_{F T}^{2}$ is a goodness of fit estimate (Table 1 ). Note: *fixed $N$ value. As/Fe and $\mathrm{S} / \mathrm{Fe}$ molar ratio of the solid samples are reported.

\begin{tabular}{|c|c|c|c|c|c|c|c|c|c|c|c|}
\hline Sample & Origin & $\mathrm{As} / \mathrm{Fe} \mathrm{mol} / \mathrm{mol}$ & $\mathrm{S} / \mathrm{Fe} \mathrm{mol} / \mathrm{mol}$ & $R(\AA)$ & $N$ & $\sigma(\AA)$ & $R(\AA)$ & $N$ & $\sigma(\AA)$ & $\chi_{F T}^{2}$ & $\Delta E_{0}(\mathrm{eV})$ \\
\hline As3_0.04_ads & Abiotic lab sample & $0.04(1)$ & $0.18(6)$ & 1.77 & $3.00 \mathrm{AsO}$ & 0.07 & $\begin{array}{l}2.94 \\
3.21 \\
3.41\end{array}$ & $\begin{array}{l}0.3 \mathrm{AsFe} \\
\text { 6.0 AsOO } \\
1.8 \mathrm{AsFe}\end{array}$ & 0.08 & 0.06 & 15 \\
\hline As3_0.05 & Abiotic lab sample & $0.03(1)$ & $0.21(1)$ & 1.79 & $3.05 \mathrm{AsO}$ & 0.06 & $\begin{array}{l}2.95 \\
3.17 \\
3.41\end{array}$ & $\begin{array}{l}0.7 \mathrm{AsFe} \\
\text { 6.0 AsOO } \\
2.6 \mathrm{AsFe}\end{array}$ & 0.11 & 0.04 & 16 \\
\hline As3_0.1 & Abiotic lab sample & $0.06(1)$ & $0.22(1)$ & 1.79 & $2.65 \mathrm{AsO}$ & 0.06 & $\begin{array}{l}2.94 \\
3.18 \\
3.41\end{array}$ & $\begin{array}{l}0.7 \mathrm{AsFe}^{*} \\
\text { 6.0 AsOO } \\
\text { 2.7 AsFe }\end{array}$ & 0.11 & 0.04 & 16 \\
\hline As3_0.2 & Abiotic lab sample & $0.10(1)$ & $0.19(4)$ & 1.79 & $2.80 \mathrm{AsO}$ & 0.06 & $\begin{array}{l}2.97 \\
3.21 \\
3.41\end{array}$ & $\begin{array}{l}0.7 \mathrm{AsFe} \\
6.0 \mathrm{AsOO}^{*} \\
2.7 \mathrm{AsFe}\end{array}$ & 0.11 & 0.06 & 16 \\
\hline As3_0.4 & Abiotic lab sample & $0.16(2)$ & $0.24(1)$ & 1.79 & $2.85 \mathrm{AsO}$ & 0.06 & $\begin{array}{l}2.95 \\
3.22 \\
3.41\end{array}$ & $\begin{array}{l}0.5 \mathrm{AsFe} \\
6.0 \mathrm{AsOO}^{*} \\
2.5 \mathrm{AsFe}\end{array}$ & 0.10 & 0.06 & 15 \\
\hline As3_0.6 & Abiotic lab sample & $0.21(2)$ & $0.22(1)$ & 1.79 & $2.80 \mathrm{AsO}$ & 0.06 & $\begin{array}{l}2.94 \\
3.27 \\
3.41\end{array}$ & $\begin{array}{l}0.8 \mathrm{AsFe} \\
6.0 \mathrm{AsOO}^{*} \\
2.3 \mathrm{AsFe}\end{array}$ & 0.10 & 0.03 & 17 \\
\hline Af $\mathrm{CC} 1$ & Biogenic lab sample & $0.19(1)$ & n.d. & 1.79 & $3.45 \mathrm{AsO}$ & 0.07 & $\begin{array}{l}2.91 \\
3.28 \\
3.41\end{array}$ & $\begin{array}{l}0.8 \mathrm{AsFe}^{*} \\
6.0 \mathrm{AsOO}^{*} \\
2.1 \mathrm{AsFe}^{2}\end{array}$ & 0.10 & 0.07 & 17 \\
\hline
\end{tabular}


Table 3

Results of shell-by-shell fitting of unfiltered EXAFS data at the Fe K-edge for the $\mathrm{As}(\mathrm{V})$ samples studied. $R(\AA)$ : interatomic distance; $N$ : number of neighbors; $\sigma(\AA)$ : Debye Waller factor; $\Delta E_{0}(\mathrm{eV})$ : difference between the experimentally determined threshold energy and the FEFF8-calculated threshold energy, without using the self-consistent potential calculation; Standard deviations of these fit parameters are $0.02 \AA, \pm 30 \%, 0.01 \AA$, and $2 \mathrm{eV}$, respectivel $\chi_{F T}^{2}$ is a goodness of fit estimate.(Table. 1).

\begin{tabular}{|c|c|c|c|c|c|c|c|c|c|c|c|c|c|}
\hline Sample & Origin & $\mathrm{As} / \mathrm{Fe} \mathrm{mol} / \mathrm{mol}$ & $\mathrm{S} / \mathrm{Fe} \mathrm{mol} / \mathrm{mol}$ & $R(\AA)$ & $N$ & $\sigma(\AA)$ & $R(\AA)$ & $N$ & $R(\AA)$ & $N$ & $\sigma(\AA)$ & $\chi_{F T}^{2}$ & $\Delta E_{0}(\mathrm{eV})$ \\
\hline \multirow[t]{4}{*}{ As free } & Abiotic lab sample & 0.00 & n.d. & 1.94 & $3.15 \mathrm{FeO}$ & 0.08 & 3.03 & $1.2 \mathrm{FeFe}$ & 5.53 & $0.8 \mathrm{FeFe}$ & 0.06 & 0.02 & -2 \\
\hline & & & & 2.07 & $1.93 \mathrm{FeO}$ & - & 3.31 & $0.7 \mathrm{FeFe}$ & 6.03 & $0.6 \mathrm{FeFeFeFe}$ & - & & \\
\hline & & & & & & & 3.40 & $24.0 \mathrm{FeOO}^{*}$ & & & - & & \\
\hline & & & & & & & 3.42 & $1.1 \mathrm{FeFe}$ & & & - & & \\
\hline \multirow[t]{4}{*}{ As5_0.05 } & Abiotic lab sample & $0.05(1)$ & n.d. & 1.94 & $2.85 \mathrm{FeO}$ & 0.08 & 3.03 & $1.2 \mathrm{FeFe}$ & 5.53 & $0.9 \mathrm{FeFe}$ & 0.07 & 0.02 & -2 \\
\hline & & & & 2.06 & $2.00 \mathrm{FeO}$ & - & 3.29 & $0.7 \mathrm{FeFe}$ & 6.02 & $0.6 \mathrm{FeFeFeFe}$ & - & & \\
\hline & & & & & & & 3.37 & $24.0 \mathrm{FeOO}^{*}$ & & & - & & \\
\hline & & & & & & & 3.41 & $1.3 \mathrm{FeFe}$ & & & - & & \\
\hline \multirow{4}{*}{ As5_0.1 } & Abiotic lab sample & $0.13(1)$ & $0.20(2)$ & 1.91 & $2.50 \mathrm{FeO}$ & 0.07 & 3.01 & $0.7 \mathrm{FeFe}$ & 5.46 & $0.4 \mathrm{FeFe}$ & 0.06 & 0.02 & -4 \\
\hline & & & & 2.04 & $2.45 \mathrm{FeO}$ & - & 3.32 & $0.8 \mathrm{FeFe}$ & 6.00 & $0.3 \mathrm{FeFeFeFe}$ & - & & \\
\hline & & & & & & & 3.34 & $24.0 \mathrm{FeOO}^{*}$ & & & - & & \\
\hline & & & & & & & 3.43 & $0.9 \mathrm{FeFe}$ & & & - & & \\
\hline \multirow[t]{4}{*}{ As5_0.2 } & Abiotic lab sample & $0.24(1)$ & $0.16(6)$ & 1.93 & $2.40 \mathrm{FeO}$ & 0.07 & 3.03 & $0.9 \mathrm{FeFe}$ & 5.50 & $0.6 \mathrm{FeFe}$ & 0.07 & 0.01 & -2 \\
\hline & & $0.85(2)^{\mathrm{v}}$ & & 2.05 & $2.40 \mathrm{FeO}$ & - & 3.31 & $0.4 \mathrm{FeFe}$ & 6.02 & $0.4 \mathrm{FeFeFeFe}$ & - & & \\
\hline & & & & & & & 3.39 & $24.0 \mathrm{FeOO}^{*}$ & & & - & & \\
\hline & & & & & & & 3.41 & $0.9 \mathrm{FeFe}$ & & & - & & \\
\hline \multirow[t]{5}{*}{ Sed arch0503 } & AMD sample & $0.45(1)$ & $0.18(1)$ & 1.98 & $4.95 \mathrm{FeO}$ & 0.09 & 3.04 & $0.5 \mathrm{FeFe}$ & 3.92 & $6.0 \mathrm{FeOFeO}^{*}$ & 0.08 & 0.01 & -2 \\
\hline & & $0.77(2)^{\mathrm{v}}$ & & & & & 3.30 & $0.4 \mathrm{FeAs}$ & 6.02 & $0.2 \mathrm{FeFeFeFe}$ & - & & \\
\hline & & & & & & & 3.39 & $24.0 \mathrm{FeOO}^{*}$ & & & - & & \\
\hline & & & & & & & 3.42 & $0.7 \mathrm{FeFe}$ & & & - & & \\
\hline & & & & & & & 3.61 & $0.7 \mathrm{FeFe}$ & & & - & & \\
\hline \multirow[t]{3}{*}{ As5_0.4 } & Abiotic lab sample & $0.48(2)$ & $0.18(2)$ & 1.98 & $5.20 \mathrm{FeO}$ & 0.09 & 3.32 & $1.8 \mathrm{FeAs}$ & 3.91 & $6.0 \mathrm{FeOFeO}^{*}$ & 0.10 & 0.01 & -2 \\
\hline & & & & & & & 3.43 & $24.0 \mathrm{FeOO}^{*}$ & & & - & & \\
\hline & & & & & & & 3.60 & $1.5 \mathrm{FeFe}$ & & & - & & \\
\hline \multirow[t]{3}{*}{ Sed S32F00 } & AMD sample & $0.62(2)$ & $0.09(1)$ & 1.99 & $5.25 \mathrm{FeO}$ & 0.08 & 3.31 & $2.8 \mathrm{FeAs}$ & 3.89 & $6.0 \mathrm{FeOFeO}^{*}$ & 0.10 & 0.02 & -2 \\
\hline & & $0.93(2)^{\mathrm{v}}$ & & & & & 3.44 & $24.0 \mathrm{FeOO}^{*}$ & & & - & & \\
\hline & & & & & & & 3.60 & $2.2 \mathrm{FeFe}$ & & & - & & \\
\hline \multirow[t]{3}{*}{$\operatorname{Tm} \mathrm{B} 2$} & $\begin{array}{l}\text { Biogenic lab } \\
\text { sample }\end{array}$ & $0.63(2)$ & n.d. & 1.98 & $5.30 \mathrm{FeO}$ & 0.09 & 3.32 & $2.5 \mathrm{FeAs}$ & 3.90 & $6.0 \mathrm{FeOFeO}^{*}$ & 0.10 & 0.01 & -3 \\
\hline & & & & & & & 3.49 & $24.0 \mathrm{FeOO}^{*}$ & & & - & & \\
\hline & & & & & & & 3.60 & $2.0 \mathrm{FeFe}$ & & & - & & \\
\hline \multirow[t]{3}{*}{ Tm B3 } & $\begin{array}{l}\text { Biogenic lab } \\
\text { sample }\end{array}$ & $0.80(2)$ & $0.12(1)$ & 1.99 & $5.20 \mathrm{FeO}$ & 0.09 & 3.32 & $3.0 \mathrm{FeAs}$ & 3.90 & $6.0 \mathrm{FeOFeO}^{*}$ & 0.10 & 0.02 & -2 \\
\hline & & & & & & & 3.50 & $24.0 \mathrm{FeOO}^{*}$ & & & - & & \\
\hline & & & & & & & 3.60 & $2.3 \mathrm{FeFe}$ & & & - & & \\
\hline \multirow[t]{3}{*}{ As5_0.8 } & Abiotic lab sample & $0.78(2)$ & $0.10(3)$ & 1.98 & $5.15 \mathrm{FeO}$ & 0.09 & 3.32 & $2.2 \mathrm{FeAs}$ & 3.93 & $6.0 \mathrm{FeOFeO}^{*}$ & 0.10 & 0.01 & -3 \\
\hline & & & & & & & 3.46 & $24.0 \mathrm{FeOO}^{*}$ & & & - & & \\
\hline & & & & & & & 3.61 & $1.5 \mathrm{FeFe}$ & & & - & & \\
\hline
\end{tabular}

Note: $\operatorname{vAs}(\mathrm{V}) /$ AsTotal when lower than $1.00 ;{ }^{*}$ fixed $N$ value. 
Table 4

Results of shell-by-shell fitting of unfiltered EXAFS data at the As K-edge for the As(V) samples studied. $R(\AA)$ : interatomic distance; $N$ : number of neighbors; $\sigma(\AA)$ : Debye Waller factor; $\Delta E_{0}(\mathrm{eV})$ : difference between the experimentally determined threshold energy and the FEFF8-calculated threshold energy, without using the self-consistent potential calculation; Standard deviations of these fit parameters are $0.02 \AA, \pm 15 \%$ and $\pm 30 \%$ for first and second neighbors respectively, $0.01 \AA$, and $2 \mathrm{eV}$, respectively $\chi_{F T}^{2}$ is a goodness of fit estimate (Table 1 ). Note: ${ }^{\mathrm{v}} \mathrm{As}(\mathrm{V}) /$ AsTotal when lower than $1.00 ;{ }^{*}$ fixed $N$ value.

\begin{tabular}{|c|c|c|c|c|c|c|c|}
\hline Sample & As/Fe solid & $\mathrm{S} / \mathrm{Fe} \mathrm{mol} / \mathrm{mol}$ & $R(\AA)$ & $N$ & $\sigma(\AA)$ & $\chi_{F T}^{2}$ & $\Delta E_{0}(\mathrm{eV})$ \\
\hline \multirow[t]{5}{*}{ As5_ads } & $0.09(2)$ & $0.17(1)$ & 1.68 & $4.1 \mathrm{AsO}$ & 0.05 & 0.07 & 3 \\
\hline & & & 3.11 & $12.0 \mathrm{AsOO}^{*}$ & - & & \\
\hline & & & 3.20 & 4.0 $\mathrm{AsOAsO}^{*}$ & - & & \\
\hline & & & 3.27 & $1.5 \mathrm{AsFe}$ & 0.07 & & \\
\hline & & & 4.35 & $4.9 \mathrm{AsOO}$ & & & \\
\hline \multirow[t]{5}{*}{ As5_0.025 } & $0.03(1)$ & n.d. & 1.69 & 4.6 $\mathrm{AsO}$ & 0.05 & 0.07 & 5 \\
\hline & & & 3.12 & $12.0 \mathrm{AsOO}^{*}$ & - & & \\
\hline & & & 3.30 & 4.0 $\mathrm{AsOAsO}^{*}$ & - & & \\
\hline & & & 3.30 & $2.0 \mathrm{AsFe}$ & 0.08 & & \\
\hline & & & 4.34 & $8.0 \mathrm{AsOO}$ & & & \\
\hline \multirow[t]{5}{*}{ As5_0.05 } & $0.05(1)$ & n.d. & 1.69 & $4.4 \mathrm{AsO}$ & 0.05 & 0.08 & 4 \\
\hline & & & 3.13 & $12.0 \mathrm{AsOO}^{*}$ & - & & \\
\hline & & & 3.31 & 4.0 $\mathrm{AsOAsO}^{*}$ & - & & \\
\hline & & & 3.30 & $1.9 \mathrm{AsFe}$ & 0.08 & & \\
\hline & & & 4.34 & 7.2 AsOO & & & \\
\hline \multirow[t]{5}{*}{ As5_0.1 } & $0.13(1)$ & $0.20(2)$ & 1.69 & $4.4 \mathrm{AsO}$ & 0.05 & 0.08 & 5 \\
\hline & & & 3.12 & 12.0 AsOO* $^{*}$ & - & & \\
\hline & & & 3.30 & 4.0 AsOAsO* & - & & \\
\hline & & & 3.31 & $1.9 \mathrm{AsFe}$ & 0.08 & & \\
\hline & & & 4.36 & 7.1 AsOO & & & \\
\hline \multirow[t]{5}{*}{ As5_0.2 } & $0.24(1)$ & $0.16(6)$ & 1.68 & $4.0 \mathrm{AsO}$ & 0.05 & 0.06 & 3 \\
\hline & $0.80(2)^{\mathrm{v}}$ & & 3.12 & $12.0 \mathrm{AsOO}^{*}$ & - & & \\
\hline & & & 3.24 & 4.0 $\mathrm{AsOAsO}^{*}$ & - & & \\
\hline & & & 3.30 & $1.9 \mathrm{AsFe}$ & 0.08 & & \\
\hline & & & 4.33 & $6.0 \mathrm{AsOO}$ & & & \\
\hline \multirow[t]{5}{*}{ As5_0.4 } & $0.48(2)$ & $0.18(2)$ & 1.68 & $4.5 \mathrm{AsO}$ & 0.05 & 0.05 & 5 \\
\hline & & & 3.12 & $12.0 \mathrm{AsOO}^{*}$ & - & & \\
\hline & & & 3.26 & 4.0 $\mathrm{AsOAsO}^{*}$ & - & & \\
\hline & & & 3.31 & $1.7 \mathrm{AsFe}$ & 0.07 & & \\
\hline & & & 4.39 & $6.2 \mathrm{AsOO}$ & & & \\
\hline \multirow[t]{5}{*}{ As5_0.8 } & $0.78(2)$ & $0.10(3)$ & 1.68 & $4.2 \mathrm{AsO}$ & 0.05 & 0.05 & 4 \\
\hline & & & 3.16 & $12.0 \mathrm{AsOO}^{*}$ & - & & \\
\hline & & & 3.21 & 4.0 AsOAsO & - & & \\
\hline & & & 3.32 & 2.0 AsFe & 0.08 & & \\
\hline & & & 4.41 & $7.3 \mathrm{AsOO}$ & & & \\
\hline \multirow[t]{5}{*}{ Sed $\operatorname{arch} 0503$} & $0.45(1)$ & $0.18(1)$ & 1.68 & $3.9 \mathrm{AsO}$ & 0.05 & 0.04 & 3 \\
\hline & $0.77(2)^{\mathrm{v}}$ & & 3.11 & $12.0 \mathrm{AsOO}^{*}$ & - & & \\
\hline & & & 3.26 & 4.0 $\mathrm{AsOAsO}^{*}$ & - & & \\
\hline & & & 3.30 & $1.9 \mathrm{AsFe}$ & 0.08 & & \\
\hline & & & 4.36 & $6.1 \mathrm{AsOO}$ & & & \\
\hline \multirow[t]{5}{*}{ Sed S32F00 } & $0.62(2)$ & $0.09(1)$ & 1.68 & $4.3 \mathrm{AsO}$ & 0.05 & 0.04 & 2 \\
\hline & $0.93(2)^{\mathrm{v}}$ & & 3.12 & 12.0 AsOO $^{*}$ & - & & \\
\hline & & & 3.25 & 4.0 $\mathrm{AsOAsO}^{*}$ & - & & \\
\hline & & & 3.31 & 1.9 AsFe & 0.07 & & \\
\hline & & & 4.38 & $6.1 \mathrm{AsOO}$ & & & \\
\hline \multirow[t]{5}{*}{$\operatorname{Tm} \mathrm{B} 2$} & $0.63(2)$ & n.d. & 1.68 & $4.3 \mathrm{AsO}$ & 0.05 & 0.04 & 2 \\
\hline & & & 3.14 & $12.0 \mathrm{AsOO}^{*}$ & - & & \\
\hline & & & 3.21 & 4.0 $\mathrm{AsOAsO}^{*}$ & - & & \\
\hline & & & 3.31 & $2.0 \mathrm{AsFe}$ & 0.08 & & \\
\hline & & & 4.40 & 6.6 AsOO & & & \\
\hline \multirow[t]{5}{*}{ Tm B3 } & $0.80(2)$ & $0.12(1)$ & 1.69 & 4.6 AsO & 0.06 & 0.05 & 3 \\
\hline & & & 3.16 & 12.0 AsOO $^{*}$ & - & & \\
\hline & & & 3.25 & 4.0 $\mathrm{AsOAsO}^{*}$ & - & & \\
\hline & & & 3.32 & $1.5 \mathrm{AsFe}$ & 0.07 & & \\
\hline & & & 4.45 & $5.7 \mathrm{AsOO}$ & & & \\
\hline
\end{tabular}



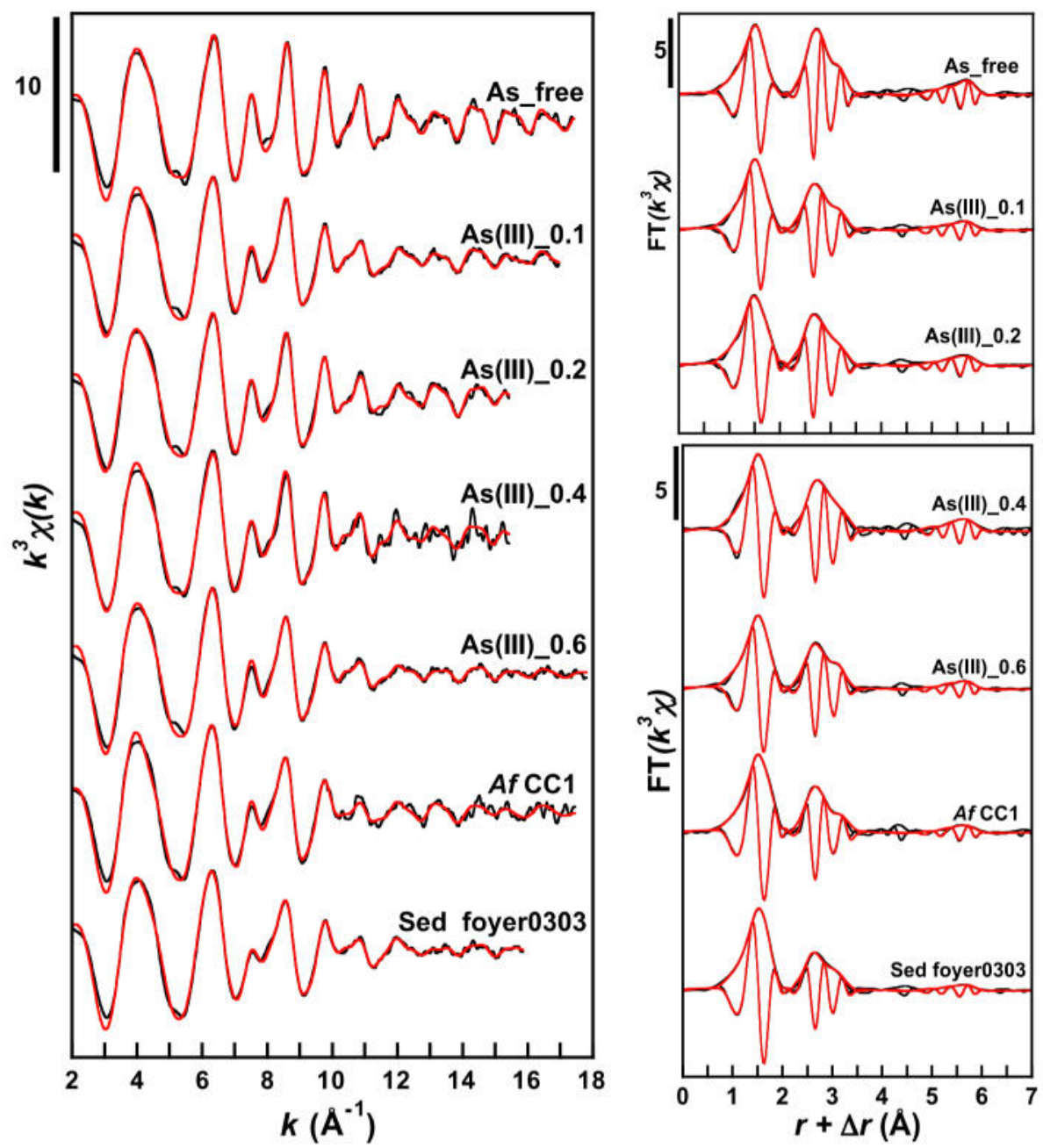

Fig. 4. Unfiltered $k^{3}$-weighted EXAFS data at the Fe K-edge for the As(III) samples studied, and corresponding amplitude and imaginary parts of the Fourier transform. Experimental and fit curves are displayed in black and red color respectively. Fit parameters are reported in Table 1. (For interpretation of the references to colour in this figure legend, the reader is referred to the web version of this article.)

$\left.N_{2.9}=6\right)$ and larger than that observed for the AMD samples and for those prepared by precipitating schwertmannite in the presence of dissolved $\operatorname{As}(\mathrm{III})\left(N_{3.4} / N_{2.9}=2.7-\right.$ 5.4). This trend, although less marked for the As_0.4 sample, indicates that the As(III) adsorption process observed when As(III) interacts with already formed schwertmannite differs slightly from that obtained after schwertmannite precipitation in the presence of As(III). Because As-Fe pairs at distances of 2.9 and $3.4 \AA$ are generally assigned to bidentate edge sharing ${ }^{2} E$ and corner sharing ${ }^{2} \mathrm{C} \mathrm{As}$ (III) surface complexes, respectively (Ona-Nguema et al., 2005; Hohmann et al., 2011), our EXAFS results suggest that the $\mathrm{As}(\mathrm{III})$ adsorption mode is dominated by ${ }^{2} \mathrm{C}$ surface complexes for all samples, and that the contribution of ${ }^{2} E$ complexes, although minor, tends to increase when As(III) interacts with schwertmannite during the nucleation and crystal growth process. Fig. 6 displays tentative structural models for such As(III) surface complexes on schwertmannite. It shows that $\mathrm{FeO}_{6}$ octahedral edges with reactive singly coordinated oxygen atoms only occur at the extremities of the double chains along the $b$-axis, and which would cor- respond to $(010)$ facets in the monoclinic akaganeite structure (Post et al., 2003) or the monoclinic schwertmannite structure (Fernandez-Martinez et al., 2010). According to the generally observed needle shape of schwertmannite crystallites, which are elongated along the $b$-axis (Cornell and Schwertmann, 2003), (010) facets likely correspond to crystal growth faces that are significantly underrepresented after the needle particles have grown. Such $(010)$ facets would, however, be available for As(III) surface complexation during the nucleation and growth stages of the schwertmannite particles (Fig. 6, right). Further interaction of $\mathrm{As}$ (III) with the needle-shaped particles is then expected to be dominated by ${ }^{2} \mathrm{C} \mathrm{As}$ (III) complexes forming on the sides of the needles and which involve two adjacent $\mathrm{FeO}_{6}$ octahedra from the $b$-axis double chains (Fig. 6, left).

\subsection{Molecular-level structure for the $\mathbf{A s}(\mathbf{V})$ samples}

Fe K-edge EXAFS data for the As(V)-samples are displayed in Fig. 7. Filtered first- and second-neighbor contributions to the EXAFS are analyzed in Figures S10 and S11. 

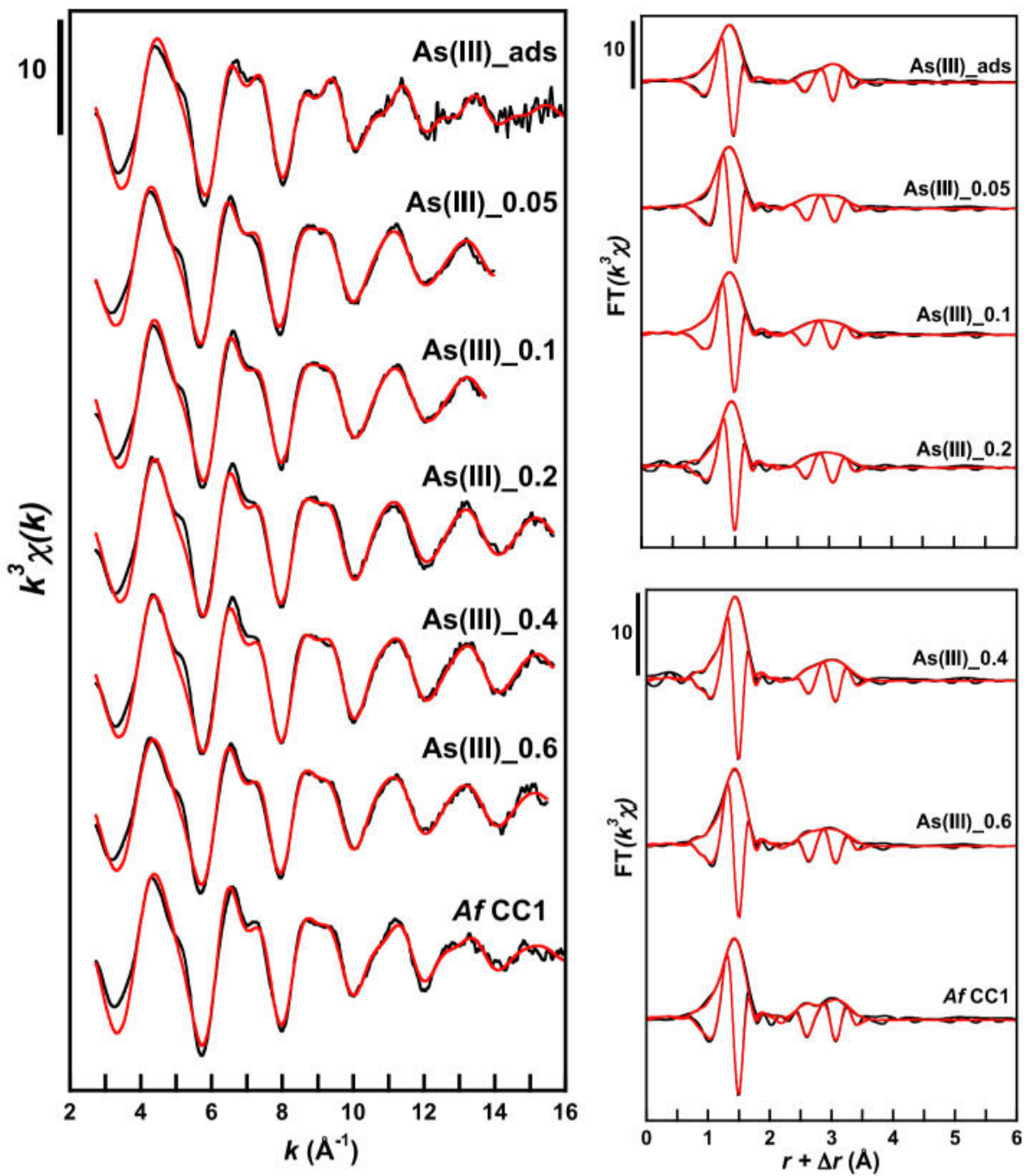

Fig. 5. Unfiltered $k^{3}$-weighted EXAFS data at the As K-edge for the As(III) samples studied, and corresponding amplitude and imaginary parts of the Fourier transform. Experimental and fit curves are displayed in black and red color respectively. Fit parameters are reported in Table 2. (For interpretation of the references to colour in this figure legend, the reader is referred to the web version of this article.)

Examination of the Fe K-edge spectra indicate a progressive change in the spectrum shape with increasing $\mathrm{As}(\mathrm{V}) /$ Fe ratio in the samples, whatever their provenance, including AMD samples as well as biotic and abiotic model compounds. $\mathrm{Up}$ to an initial $\mathrm{As}(\mathrm{V}) / \mathrm{Fe}$ ratio of 0.2 , the samples exhibit a schwertmannite-like local structure, whereas for higher $\mathrm{As} / \mathrm{Fe}$ ratios, the spectrum progressively changes toward that of amorphous ferric arsenate, which was identified by XRD as the main component in these latter samples (Fig. 3). According to our fit results for the Fe K-edge EXAFS data (Table 3), the local structure of this XRD-amorphous phase is characterized by $\mathrm{Fe}-\mathrm{As}$ pairs at $3.3 \AA$ and $\mathrm{Fe}-\mathrm{Fe}$ pairs at $3.6 \AA$ (Fig. S12). The $\mathrm{Fe}-\mathrm{Fe}$ pairs at shorter distances $(3.0,3.3$, and $3.4 \AA$ ), as well as the $\mathrm{Fe}-\mathrm{Fe}$ paths and $\mathrm{MS} \mathrm{Fe}-\mathrm{Fe}-\mathrm{Fe}-\mathrm{Fe}$ paths at longer distance, which are indicative of the schwertmannite-akaganeite-goethite local structure, are absent in this phase. Although the $\mathrm{Fe}-\mathrm{As}$ pairs at $3.3 \AA$ cannot be easily distin- guished from $\mathrm{Fe}-\mathrm{Fe}$ pairs because backscattering amplitude functions of $\mathrm{Fe}$ and As do not differ significantly, the goodness of fit indicator $\chi_{F T}^{2}$ was significantly better when assuming As instead of $\mathrm{Fe}$ second neighbors at this distance (data not shown). More importantly, the dominant secondneighbor contribution around arsenic to the As K-edge EXAFS data of the same samples is an As-Fe pair at the same distance of $3.3 \AA$ (Fig. 8, Table 4). The first coordination shell around $\mathrm{Fe}$ observed by EXAFS at the Fe K-edge in the amorphous ferric arsenate phase (Fig. 7) is fit with $\sim 5$ oxygen atoms at a distance of $1.985 \pm 0.02 \AA$, which indicates that $\mathrm{Fe}$ (III) is likely octahedrally coordinated to oxygen in this phase (note that the $\mathrm{S}_{0}{ }^{2}$ factor was set to 1 ; see Section 2). This first coordination shell can be fit with only one oxygen shell (Figs. S10 and S12), which differs from ferric oxyhydroxides for which two shells are necessary to account for the $\mathrm{FeO}_{6}$ octrahedral distortion (Maillot et al., 2011). Although the $\mathrm{Fe}-\mathrm{O}$ distance measured by EXAFS 


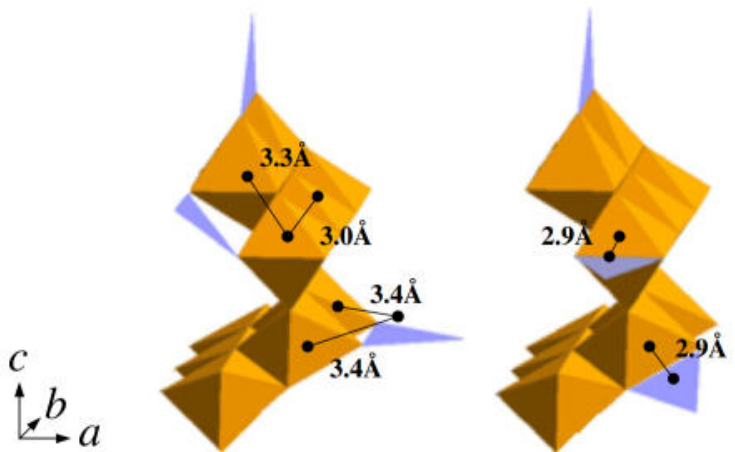

Fig. 6. Tentative structural models for As(III) surface complexes on schwertmannite that are consistent with our EXAFS data at the As $\mathrm{K}$-edge. The $3 \mathrm{D}$ view is drawn according to the local structure of akaganeite in monoclinic (SG $I 2 / \mathrm{m}$ ) unit cell (Post et al. 2003). ${ }^{2} \mathrm{C} \mathrm{As}$ (III) surface complexes, forming on the sides of the $\mathrm{FeO}_{6}$ octahedra double-chains, dominate over ${ }^{2} E$ complexes in the case of adsorption on already formed schwertmannite (left), while the contribution of ${ }^{2} E$ complexes forming on the extremities of the $\mathrm{FeO}_{6}$ octahedra double-chains, i.e., $(010)$ facets, increases in the case of precipitation of schwermannite in the presence of dissolved As(III) (left). Nevertheless, both type of processes only lead to surface adsorption of $\mathrm{As}(\mathrm{III})$ and the As/Fe molar ratio of the solid phase does not exceeds 0.25 in our experiments and in the AMD samples studied (Table 2).

in amorphous ferric arsenate $(1.985 \pm 0.02 \AA)$ is slightly lower than that measured by EXAFS in ferric (oxyhydr)oxides in which $\mathrm{Fe}(\mathrm{III})$ is octahedrally coordinated $(2.01 \pm 0.01 \AA$ in goethite, $2.00 \pm 0.01 \AA$ in akaganeite; Maillot et al., 2011), it is, however, larger than the $<\mathrm{Fe}-$ $\mathrm{O}>$ measured by EXAFS in compounds containing a mixture of octahedrally and tetrahedrally coordinated $\mathrm{Fe}(\mathrm{III})$ $(1.97 \pm 0.01 \AA$ in ferrihydrite, $1.96 \pm 0.01 \AA$ in maghemite; Maillot et al., 2011). Moreover, the absence of tetrahedrally coordinated $\mathrm{Fe}(\mathrm{III})$ in amorphous ferric arsenate is fully confirmed by the smaller intensity of the $\mathrm{Fe} \mathrm{K}$-pre-edge intensity for this compound compared to other mineral phases such as goethite and akaganeite, in which $\mathrm{Fe}$ (III) is solely octahedral (Fig. S13). This smaller intensity of the pre-edge feature, as well as the fact that the first-neighbor contribution to the EXAFS can be fit using only one oxygen shell, might be related to a more regular $\mathrm{FeO}_{6}$ octahedron than in Fe(III) oxyhydroxides. Such lack of octahedral distortion could be explained by the absence of longrange order in this amorphous phase, which may favor relaxation of the local structure, or by the absence of edgeor face-sharing between $\mathrm{Fe}(\mathrm{III}) \mathrm{O}_{6}$ octahedra in these amorphous ferric arsenate phases. Indeed, these types of polyhedral linkages create local displacement of the iron atoms from the center of their octahedra, due to cation-cation repulsion, as illustrated by the distorted octahedral in the structure of $(\alpha-\mathrm{FeOOH})$ goethite or hematite $\left(\alpha-\mathrm{Fe}_{2} \mathrm{O}_{3}\right)$. The As-Fe and $\mathrm{Fe}-\mathrm{Fe}$ linkages observed in our EXAFS data for all amorphous ferric arsenate samples investigated here, either from AMD or from the biotic and abiotic syntheses, are similar to those reported by Paktunc et al. (2008) for synthetic amorphous ferric arsenate. The $\mathrm{Fe}-\mathrm{Fe}$ distance at $3.6 \AA$ corresponds to corner linkage $\left({ }^{2} C\right)$ between tilted $\mathrm{Fe}(\mathrm{O}, \mathrm{OH})_{6}$ octahedra, and the As- $\mathrm{Fe}$ distance at $3.3 \AA$ corresponds to arsenate corner linkage $\left({ }^{2} C\right)$ to adjacent $\mathrm{Fe}(\mathrm{O}, \mathrm{OH})_{6}$ octahedra, which is consistent with the local chain structure found in the ferric sulfate minerals butlerite, parabutlerite, and fibroferrite (Paktunc et al., 2008). It is also interesting to note that such linkages are consistent with the ring local structure of jarosite, and its lead-arsenate isotype beudantite (Fig. 9). However, the number of $\mathrm{Fe}(\mathrm{III})$ second neighbors around $\mathrm{As}(\mathrm{V})$ in jarosite and beudanite is 3 instead of 2 for a single-chain model as present in butlerite, parabutlerite, and fibroferrite. According to our As K-edge EXAFS results (Table 4), the observed number of $\mathrm{Fe}$ neighbors around $\mathrm{As}(\mathrm{V})$ at $3.3 \AA$ ranges between 1.5 and $2.0 \pm 0.5 \mathrm{Fe}$ atoms, which supports a single-chain model rather than a jarosite/beudantite model with $3 \mathrm{Fe}$ neighbors. Besides, as shown in Fig. 9, a single-ring model, based on a modified jarosite/ beudantite structure, could match the EXAFS results as well as the butlerite, parabutlerite, and fibroferrite singlechains models.

Arsenic $\mathrm{K}$-edge EXAFS data for the $\mathrm{As}(\mathrm{V})$-containing samples are displayed in Fig. 8. Detailed analysis of the second-neighbor atoms around the absorbing arsenate oxoanion is reported in Fig. S14. It is noteworthy that the shape of the spectrum as well as the fit results remain similar for the whole set of samples, irrespective of their As/Fe ratio, including adsorption experiments, abiotic or biotic precipitation pathways, as well as field AMD samples. The first coordination shell around arsenic was fit with $4.0 \pm 0.5$ oxygen atoms at a distance of $1.69 \pm 0.02 \AA$, which is characteristic of the $\mathrm{AsO}_{4}$ tetrahedron. The second-neighbor contribution to the EXAFS was fit with $1.5-2.0 \pm 0.5 \mathrm{Fe}$ atoms at a distance of $3.3 \pm 0.05 \AA$, which is consistent with the binding of an $\mathrm{AsO}_{4}$ tetrahedron with two $\mathrm{FeO}_{6}$ octrahedra via double corner linkage $\left({ }^{2} C\right.$ complex geometry). This surface complex binding mode is the most commonly observed one for arsenate surface complexes on ferric oxyhydroxides such as ferrihydrite, goethite (Hohmann et al., 2011 and references therein), and maghemite (Morin et al., 2008). This geometry is also consistent with the local structure of amorphous ferric arsenate (Fig. 9) observed in our samples with $\mathrm{As} / \mathrm{Fe}$ ratios above 0.2 , as discussed above. It is also noted that the same As-Fe distance occurs in scorodite (Fig. S15). However, EXAFS data for amorphous ferric arsenate indicate a $\mathrm{Fe}-\mathrm{Fe}$ distance at $3.6 \AA$ in amorphous ferric arsenate (Fig. 9), which is absent in the scorodite structure (Fig. S15; Paktunc et al., 2008, 2010). Altogether, in the present study, the similarity between the local structure of $\mathrm{As}(\mathrm{V}) \mathrm{O}_{4}{ }^{2} \mathrm{C}$ surface complexes and that of amorphous ferric arsenate makes it difficult to determine unambiguously the molecular environment of $\mathrm{As}(\mathrm{V})$ in our arsenate samples with $\mathrm{As} / \mathrm{Fe}$ ratios below 0.2 . Indeed, $\mathrm{AsO}_{4}$ tetrahedra may be adsorbed at the surface of schwertmannite particles attached to the sides of the $\mathrm{FeO}_{6}$ octahedra double chains (Fig. 9a), or they may form minute amounts of amorphous ferric arsenate (Fig. 9b and c) that would not be detected by XRD in a mixture with schwertmannite. Both adsorbed and amorphous species could also occur simultaneously in these low As/Fe samples. 

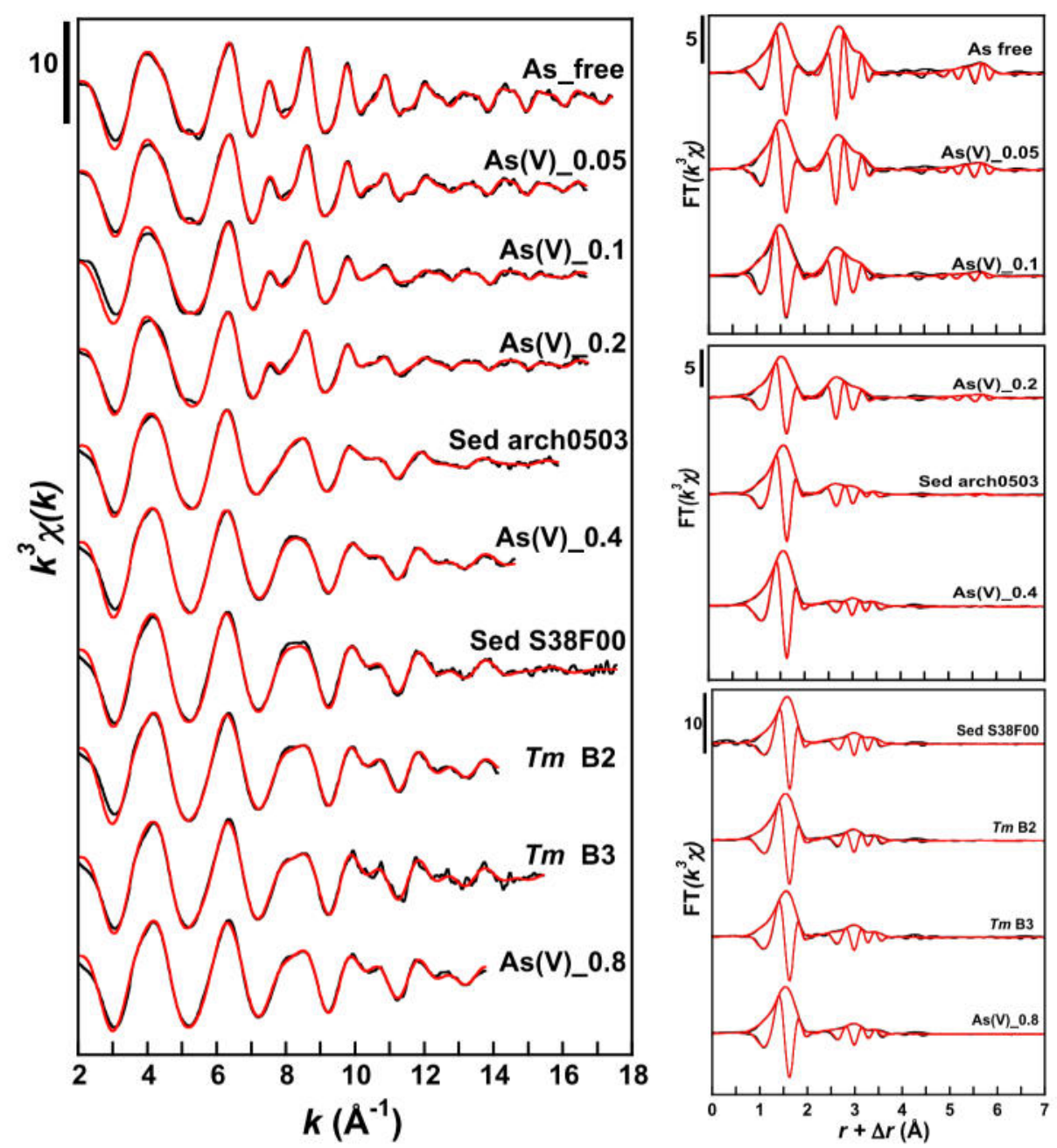

Fig. 7. Unfiltered $k^{3}$-weighted EXAFS data at the Fe K-edge for the As(V) samples studied, and corresponding amplitude and imaginary parts of the Fourier transform. Experimental and fit curves are displayed in black and red color respectively. Fit parameters are reported in Table 3. (For interpretation of the references to color in this figure legend, the reader is referred to the web version of this article.)

\subsection{Implications for $\mathbf{A s}(\mathrm{V})$ fate in AMDs}

The similarity in compositions and molecular level structures of the AMD field samples and of their biotic and abiotic synthetic analogs investigated here allows us to derive important implications about the structure and reactivity of $\mathrm{As}(\mathrm{III})$ - and $\mathrm{As}(\mathrm{V})$-rich hydroxysulfate minerals forming in AMD systems. First, in agreement with previous studies by Carlson et al. (2002) and Waychunas et al. (1995b), our results yield further evidence for the poisoning effect of $\mathrm{As}(\mathrm{V}) \mathrm{O}_{4}$ that inhibits the nucleation of schwertmannite. This effect can be directly related to the strong affinity of the $\mathrm{AsO}_{4}$ tetrahedron for binding to $\mathrm{FeO}_{6}$ octahedra, which may hinder the formation of edge-sharing linkages between $\mathrm{FeO}_{6}$ octahedra during the nucleation of schwertmannite. It is noteworthy that similar retardation of the nucleation of $\mathrm{Fe}$ oxides and oxyhydroxides have been reported in the presence of dissolved silica (Pokrovski et al., 2003), phosphate (Rose et al., 1996) or germanate (Pokrovsky et al., 2006). As a result of this strong affinity between dissolved arsenate an ferric species, an amorphous $\mathrm{Fe}(\mathrm{III})-\mathrm{As}(\mathrm{V})$ hydroxysulfate forms for initial $\mathrm{As}(\mathrm{V}) / \mathrm{Fe}$ ratios higher than 0.2 , with a local structure similar to that of amorphous ferric arsenate described by Paktunc et al. (2008). EXAFS data of amorphous ferric arsenate at the As and Fe K-edge are consistent with single chains or rings of corner-sharing $\mathrm{FeO}_{6}$ octahedra on which $\mathrm{AsO}_{4}$ tetrahedra attach via ${ }^{2} \mathrm{C}$ linkages. In the study by Paktunc et al. (2008), this phase formed at the expense of ferrihydrite, whereas in the present study it formed at the expense of schwertmannite. This difference can likely be attributed to the fact that, even though both studies were conducted in sulfate-rich systems, the study by Paktunc et al. (2008) was conducted at $\mathrm{pH} 4.5$, whereas the present study was conducted at $\mathrm{pH} 3$. Such a difference in $\mathrm{pH}$ could explain the formation of ferrihydrite instead of schwertmannite in the experiments by Paktunc et al. (2008), owing to the known stability fields of these phases (Bigham et al., 1996b). The 30 times higher starting concentration of both dissolved $\mathrm{Fe}(\mathrm{III})$ and $\mathrm{As}(\mathrm{V})(0.2 \mathrm{M}$ and $0.02-0.2 \mathrm{M}$, respectively) used by Paktunc et al. (2008) relative to those used in the present study $(6.4 \mathrm{mM}$ $\mathrm{Fe}(\mathrm{III})$ and $0.16-5.12 \mathrm{mM} \mathrm{As}(\mathrm{V}))$ is another difference that 

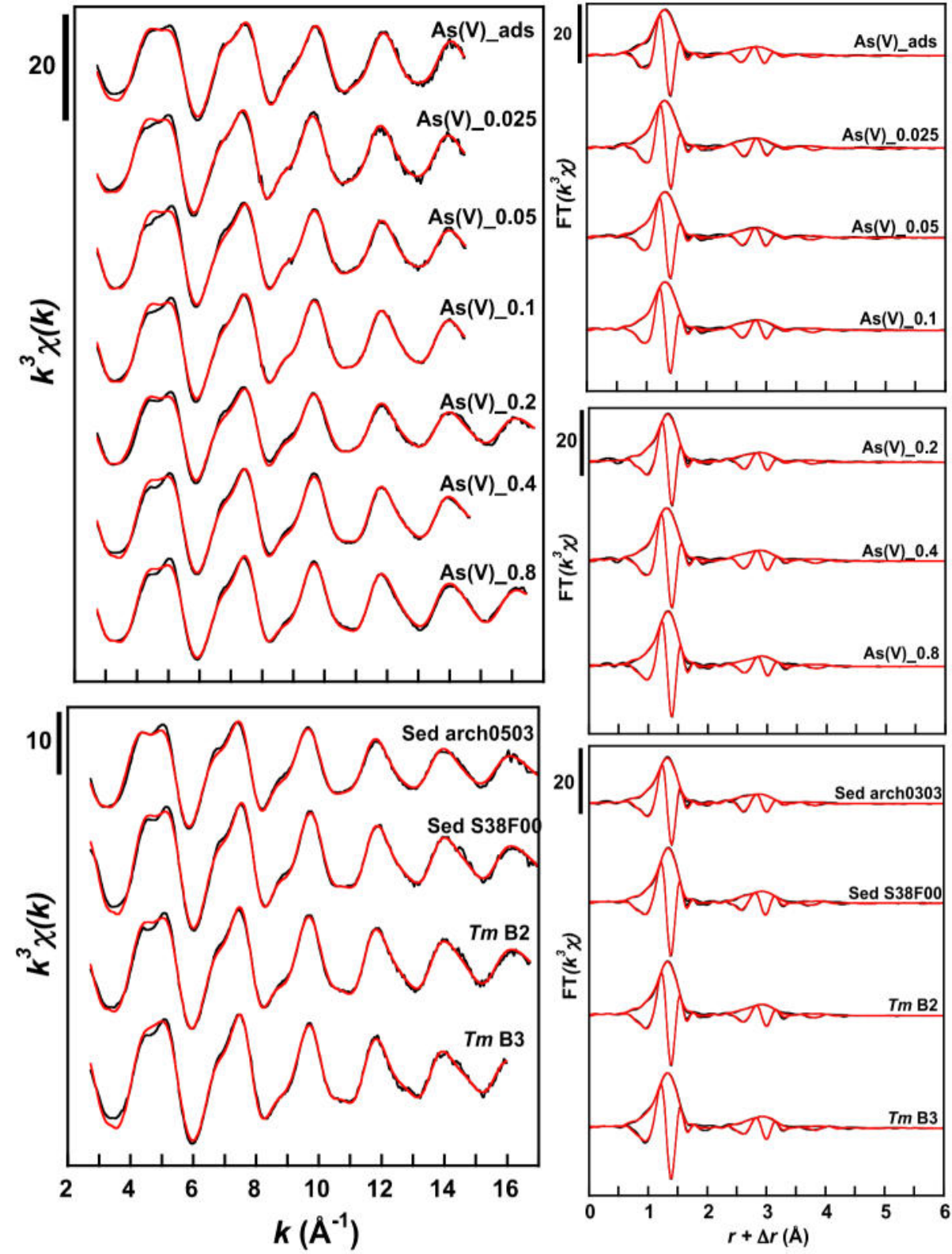

Fig. 8. Unfiltered $k^{3}$-weighted EXAFS data at the As $\mathrm{K}$-edge for the $\mathrm{As}(\mathrm{V})$ samples studied, and corresponding amplitude and imaginary parts of the Fourier transform. Experimental and fit curves are displayed in black and red color respectively. Fit parameters are reported in Table 4. (For interpretation of the references to colour in this figure legend, the reader is referred to the web version of this article.)

also could have influenced the mineral phases formed. The starting dissolved concentrations used to prepare the synthetic abiotic model compounds in the present study were chosen to better match the concentration levels of the dissolved $\mathrm{Fe}$ and $\mathrm{As}$ in the Carnoulès AMD (10-40 $\mathrm{mM}$ and 1-5 As mM, respectively; Casiot et al., 2003). To the best of our knowledge, the Carnoulès AMD is one of the most As-rich AMDs reported to date (Morin and Calas, 2006). Our results show that the $\mathrm{As}(\mathrm{V})$-bearing mineral phases synthesized under abiotic conditions in our laboratory experiments are similar to those formed after microbial incubation of sterilized AMD water from Carnoulès with As-oxidizing bacteria from the Thiomonas sp., as well as to those formed in the field. It is especially noteworthy that the evolution of $\mathrm{As}(\mathrm{V})$ and $\mathrm{Fe}$ mineralogy with increasing $\mathrm{As} / \mathrm{Fe}$ ratio is similar for the biotic and abiotic laboratory samples as well as for the field samples in the present study, as previously suggested by XRD (Carlson et al., 2002; Morin et al., 2003) and XANES (Morin et al., 2003) studies. Moreover, the present results yield direct evidence for the molecular-scale breakdown of the schwertmannite structure with increasing concentration of $\mathrm{As}(\mathrm{V})$ in the AMD system. A comparison of the EXAFS-derived local structure of amorphous ferric arsenate sulfate in the present study and that of Paktunc et al. (2008) with the EXAFS results of Inskeep et al. (2004) for the Beowulf acidic hot springs in 

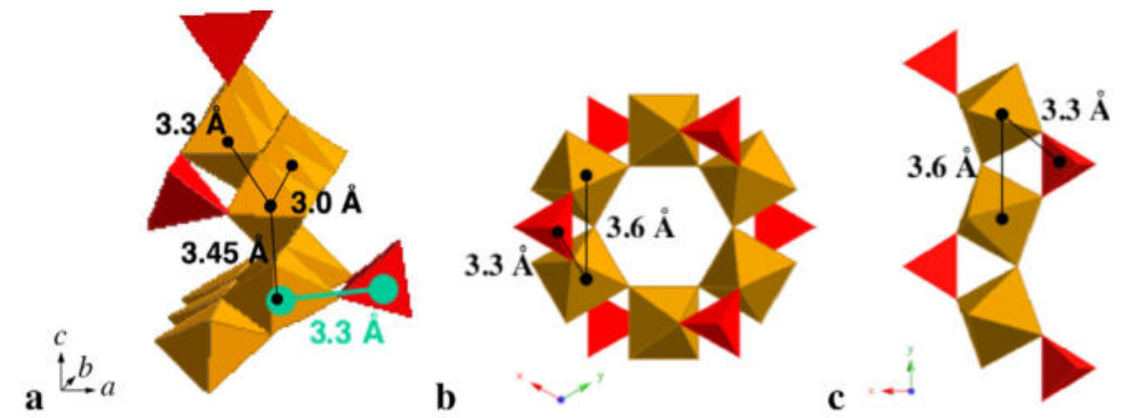

Fig. 9. Tentative structural models for $\mathrm{As}(\mathrm{V})$ speciation obtained after sorption on schwertmannite or coprecipitation with $\mathrm{SO}_{4}{ }^{2-}$ and $\mathrm{Fe}(\mathrm{III})$ at $\mathrm{pH} 3$, and which are consistent with our EXAFS data at the As and Fe K-edges. (a) Possible geometry for ${ }^{2} \mathrm{C}$ complexes adsorbed at the surface of schwertmannite. (b) Local structure of beudantite/jarosite modified to match the number of Fe neighbors $(N=1.5-2)$ measured by EXAFS around arsenic in our amorphous ferric arsenate samples. (c) Local structure of the sulfate mineral butlerite, which also matches EXAFS data of amorphous ferric arsenate when replacing sulfate tetrahedra by arsenate ones, as proposed by Paktunc et al. (2008). Other sulfate minerals as parabutlerite and fibroferrite (not shown) are also reliable candidates, as proposed by the same authors.

Yellowstone National Park, USA, shows that the structure of biogenic ferric arsenate phases forming in the acidic hot springs is similar to that of the amorphous ferric arsenate sulfate forming in AMD systems. Interestingly, the formation of this phase for dissolved $\mathrm{Fe}$ and $\mathrm{As}(\mathrm{V})$ concentrations as low as $30-50 \mu \mathrm{M}$ and $24 \mu \mathrm{M}$, respectively, indicates that the high $\mathrm{As}(\mathrm{V}) / \mathrm{Fe}(\mathrm{III})$ ratio in the aqueous phase $(0.48-0.80 \mathrm{~mol} / \mathrm{mol}$ in the Beowulf hot spring) is the driving parameter for the formation of amorphous ferric arsenate sulfate instead of schwertmannite in acidic sulfate-rich waters.

\subsection{Implications for As(III) behavior in AMDs}

The present study also shows that dissolved As(III) does not play the same role as $\mathrm{As}(\mathrm{V})$ when it is present during the precipitation of schwertmannite. These different behaviors of $\mathrm{As}(\mathrm{III})$ and $\mathrm{As}(\mathrm{V})$ are likely explained by the respective aqueous speciation of $\mathrm{As}(\mathrm{III})$ and $\mathrm{As}(\mathrm{V})$ during the nucleation stage of schwertmannite at $\mathrm{pH} 3$, with the neutral $\mathrm{H}_{3} \mathrm{As}(\mathrm{III}) \mathrm{O}_{3}$ molecule having a lower affinity than the $\mathrm{H}_{2} \mathrm{As}(\mathrm{V}) \mathrm{O}_{4}{ }^{-}$oxoanion for $\left[\mathrm{Fe}(\mathrm{OH})\left(\mathrm{H}_{2} \mathrm{O}\right)_{5}\right]^{2+}$ cations. Such differences in $\mathrm{As}(\mathrm{III})$ and $\mathrm{As}(\mathrm{V})$ speciation as a function of $\mathrm{pH}$ have been directly demonstrated by EXAFS (Perfetti et al., 2008; Testemale et al., 2011 and references therein). This difference in As(III) speciation compared to that of $\mathrm{As}(\mathrm{V})$ can explain the persistence of the schwertmannite structure for biotic and abiotic precipitation experiments in the presence of high concentrations of As(III), as well as in AMD samples (up to initial As/Fe ratio of 0.6). Indeed, our EXAFS data indicate that As(III) is adsorbed on the schwertmannite surface in all samples studied. More precisely, it forms ${ }^{2} C$ and ${ }^{2} E$ inner-sphere surface complexes on schwertmannite, similar to those observed on other Fe-minerals such as ferrihydrite and hematite (OnaNguema et al., 2005; Hohmann et al., 2011 and references therein). In addition, although ${ }^{2} \mathrm{C}$ As(III) surface complexes dominate in all AMD and synthetic schwertmannite samples studied here, the presence of dissolved As(III) during the precipitation of schwertmannite slightly increases the proportion of ${ }^{2} E$ complexes, with respect to the sorption experiments. This difference likely reflects the higher proportion of available $\mathrm{FeO}_{6}$ octahedral edges during the schwertmannite nucleation stage rather than on the surfaces of well-developed schwertmannite particles. The formation of $\mathrm{As}$ (III) ${ }^{2} C$ and ${ }^{2} E$ surface complexes is found to favor the occurrence of structural defects in schwertmannite and to moderately decrease the size of the schwertmannite crystallites; however, it does not lead to a breakdown of the structure in the AMD samples or in the synthetic As(III)-rich samples (up to an initial As/Fe ratio of 0.6 ).

\subsection{As(III)-schwertmannite vs. tooeleite}

It is important to note that we did not observe the formation of the ferric arsenite hydroxysulfate mineral tooeleite $\quad\left(\mathrm{Fe}_{6}\left(\mathrm{AsO}_{3}\right)_{4} \mathrm{SO}_{4}(\mathrm{OH})_{4} \cdot 4 \mathrm{H}_{2} \mathrm{O} ; \quad \mathrm{As}(\mathrm{III}) / \mathrm{Fe}(\mathrm{III})=0.63\right.$; Morin et al., 2007) in the abiotic and biotic synthesis experiments, although this mineral was found to form in $\mathrm{As}$ (III) and $\mathrm{Fe}(\mathrm{III})$ rich acidic sulfate waters, including the Carnoulès AMD (Morin et al., 2003, 2006), other microbial incubation experiments of sterilized Carnoulès-Reigous water (Morin et al., 2003; Egal et al., 2009), and abiotic precipitation experiments at room temperature (Nishimura and Robins, 2008). Detailed analysis of these previous studies indicates that the formation of tooeleite requires a high initial $\mathrm{As}(\mathrm{III}) / \mathrm{Fe}(\mathrm{III})$ ratio $(\geqslant 0.8)$ and a slow nucleation process that can be achieved at room temperature in abiotic experiments at $\mathrm{pH}$ 1.8-3 (Nishimura and Robins, 2008). These requirements can likely be obtained by slow microbial $\mathrm{Fe}(\mathrm{II})$ oxidation at room temperature, even at low $\mathrm{As}(\mathrm{III}) / \mathrm{Fe}$ (II) starting ratios, because the concentration of $\mathrm{Fe}(\mathrm{III})$ progressively produced by microbial oxidation may be lower than the initial As(III) concentration, thus generating high $\mathrm{As}(\mathrm{III}) / \mathrm{Fe}(\mathrm{III})$ ratios in the solution (Morin et al., 2003; Egal et al., 2009). In the present study rapid precipitation of $\mathrm{Fe}(\mathrm{III})$ and $\mathrm{As}(\mathrm{III})$ at $80^{\circ} \mathrm{C}$ for $1 \mathrm{~h}$ with starting As/Fe ratios not exceeding 0.6 in a $\mathrm{pH} 3$ solution led to the formation of As(III)-schwertmannite. Our EXAFS analysis shows that As(III) is mainly adsorbed at the surface of the schwertmannite particles in these samples, as well as in the biotic and AMD ones. Conversely, 
formation of tooeleite may improve the efficiency of As removal from the solution compared to As(III)-sorbed schwertmannite in AMD systems. Indeed, the final dissolved concentration of As(III) after tooeleite formation was found to be $\sim 2$ to 4 times lower than that measured after precipitation of As(III)-schwertmannite (Egal et al., 2009, and Fig. 1, this study, respectively).

\subsection{Implications for arsenic remediation in AMD}

Regarding the much higher residual dissolved As(III) concentrations relative to dissolved $\mathrm{As}(\mathrm{V})$ after precipitation of schwertmannite in acidic waters (Fig. 1), remediation of As-rich AMD systems is greatly improved by oxidizing As(III) to As(V), which allows the formation of $\mathrm{As}(\mathrm{V})$ hydroxysulfates exhibiting $\mathrm{As} / \mathrm{Fe}$ solid ratios similar to those of the starting solution. Importantly, dissolved $\mathrm{As}(\mathrm{V})$ concentrations in contact with these phases are found to be $\sim 10$ times lower than dissolved As(III) concentrations in contact with these phases for a similar As/Fe ratio in the solid phase (Fig. 1). These phases are $\mathrm{As}(\mathrm{V})-$ schwertmannite for low starting As/Fe ratio $(\leqslant 0.2 \mathrm{~mol} /$ $\mathrm{mol}$ ) and amorphous ferric arsenate sulfate for high starting $\mathrm{As} / \mathrm{Fe}$ ratio ( $\geqslant 0.2 \mathrm{~mol} / \mathrm{mol})$. In AMD systems, formation of such phases is accelerated by microorganisms such as Thiomonas sp., which are able to catalyze As(III) to As(V) oxidation by dissolved oxygen (Morin et al., 2003, 2006). In the Carnoulès AMD system, seasonal variations of the microbial activity of As(III)-oxidizing microorganisms likely influence the efficiency of the natural remediation process and lead to larger production of $\mathrm{As}(\mathrm{V})$ in the summer season (Morin et al., 2003, 2006). Nevertheless, aggregation and sedimentation of tooeleite and amorphous ferric arsenate sulfate in thick biofilms rapidly lower the dissolved arsenic concentration in the upstream section (first 50-100 $\mathrm{m}$ downstream the spring) of the AMD system (Casiot et al., 2003; Egal et al., 2010). Because the dissolved As concentration decreases, schwertmannite can, therefore, precipitate downstream, and it becomes the dominant solid phase in the Reigous creek sediments. The remaining dissolved arsenic thus progressively immobilizes by forming surface complexes on the surfaces of this mineral, as shown for sample Sed foyer0303 sampled in Reigous creek, $1000 \mathrm{~m}$ downstream of the acidic spring (Lebrun, 2004; Casiot et al., 2005). The present study improves our understanding of the relationships between the structure and reactivity of As-bearing nanocrystalline and amorphous phases involved in natural and (bio)technological As remediation processes.

\section{ACKNOWLEDGMENTS}

This work was supported by the CNRS - EC2CO and by SESAME IdF Grant \#1775. Portions of this research were carried out at SSRL, a national user facility operated by Stanford University on behalf of the U.S. Department of Energy, Office of Basic Energy Sciences. Support was also provided by NSF Grant EF-0830093 (Center for Environmental Implications of Nanotechnology). We acknowledge SSRL, ESRF, LURE, and ELETTRA for provision of beamtime on beamlines 11-2, BM30B, D44, and XAFS, respectively. John Bargar (SSRL), Olivier Proux (ESRF), Jean-Louis Hazemann (ESRF), Denis Testemale (ESRF), Stephanie Belin
(LURE/SOLEIL), Andrea Cognigi (ELETTRA), Luca Olivi (ELETTRA) are kindly acknowledged for their help in acquiring EXAFS data on these synchrotron beamlines. We are indebted to Christian Personné (HSM Montpellier) for having first isolated $T m$ strains B2 and B3 from the Carnoulès site. Strains CC1 was isolated from the same site and kindly donated by Violaine Bonnefoy (Laboratoire de Chimie Bactérienne, Marseille). We thank AE Owen Duckworth for handling of the manuscript and for constructive suggestions. We are also indebted to reviewer Gleb Pokrovski and an anonymous reviewer for their contribution to improve the quality of the manuscript.

\section{APPENDIX A. SUPPLEMENTARY DATA}

Supplementary data associated with this article can be found, in the online version, at http://dx.doi.org/10.1016/ j.gca.2012.11.016.

\section{REFERENCES}

Ankudinov A. L., Ravel B., Rehr J. J. and Conradson S. D. (1998) Real-space multiple-scattering calculation and interpretation of X-ray-absorption near-edge structure. Phys. Rev. B 58, 75657576

Arsène-Ploetze F., Koechler S., Marchal M., Coppee J. -Y., Chandler M., Bonnefoy V., Barakat M., Barbe V., BattagliaBrunet F., Brochier-Armanet C., Bruneel O., Bryan C., Cleiss J., Heinrich-Salmeron A., Hommais F., Joulian C., Krin E., Lieutaud A., Lièvremont D., Michel C., Muller D., Ortet P., Proux C., Siguier P., Roche D., Rouy Z., Salvignol G., Slyemi D., Talla E., Weiss S., Weissenbach J., Médigue C., and Bertin P. N. (2010) Structure, function and evolution of the Thiomonas spp. genome inferred from sequencing and comparative analysis. PLoS Genet. 6(2), e1000859.

Barham R. J. (1997) Schwertmannite: a unique mineral, contains a replaceable ligand, transforms to jarosite, hematite, and/or basic iron sulfate. J. Mater. Res. 12(10), 2751-2758.

Battaglia-Brunet F., Dictor M. C., Garrido F., Crouzet C., Morin D., Dekeyser K., Clarens M. and Baranger P. (2002) An arsenic(III)-oxidizing bacterial population: selection, characterization, and performance in reactors. J. Appl. Microbiol. 93, 656-667.

Benzerara K., Morin G., Yoon T. H., Miot J., Tyliszczak T., Casiot C., Bruneel O., Farges F. and Brown, Jr., G. E. (2008) Nanoscale study of As biomineralization in an acid mine drainage system. Geochim. Cosmochim. Acta 72, 3949-3963.

Bigham J. M., Schwertmann U., Carlson L. and Murad E. (1990) A poorly crystallized oxyhydroxysulfate of iron formed by bacterial oxidation of $\mathrm{Fe}(\mathrm{II})$ in acid mine waters. Geochim. Cosmochim. Acta 54, 2743-2758.

Bigham J. M., Schwertmann U. and Pfab G. (1996a) Influence of $\mathrm{pH}$ on mineral speciation in a bioreactor simulating acid mine drainage. Appl. Geochem. 11, 845-849.

Bigham J. M., Schwertmann U., Traina S. J., Winland R. L. and Wolf M. (1996b) Schwertmannite and the chemical modeling of iron in acid sulfate waters. Geochim. Cosmochim. Acta 60, 2111-2121.

Bruneel O., Volant A., Gallien S., Chaumande B., Casiot C., Carapito C., Bardil A., Morin G., Brown, Jr., G. E., Personne C. J., Le Paslier D., Schaeffer C., Van Dorsselaer A., Bertin P., Elbaz-Poulichet F. and Arsene-Ploetze F. (2011) Characterization of the active bacterial community involved in natural attenuation processes in arsenic-rich creek sediments. Microb. Ecol. 61(4), 793-810. 
Burgos W. D., Borch T., Troyer L. D., Luan F., Larson L. N., Juliana F., Brown J. F., Lambson J. and Shimizu M. (2012) Schwertmannite and Fe oxides formed by biological low-pH $\mathrm{Fe}(\mathrm{II})$ oxidation versus abiotic neutralization: impact on trace metal sequestration. Geochim. Cosmochim. Acta 76, 29-44.

Burton E., Bush R., Johnston S., Watling K., Hocking R., Sullivan L. and Parker G. K. (2009) Sorption of arsenic(V) and arsenic(III) to schwertmannite. Environ. Sci. Technol. 43, 9202-9207.

Carlson L., Bigham J. M., Schwertmann U., Kyek A. and Wagner F. (2002) Scavenging of As from acid mine drainage by schwertmannite and ferrihydrite: a comparison with synthetic analogues. Environ. Sci. Technol. 36, 1712-1719.

Casiot C., Lebrun S., Morin G., Bruneel O., Personné J. C. and Elbaz-Poulichet F. (2005) Sorption and redox processes controlling arsenic fate and transport in a stream impacted by acid mine drainage. Sci. Total Environ. 347, 122-130.

Casiot C., Morin G., Juillot F., Bruneel O., Personné J. C., Leblanc M., Duquesne K., Bonnefoy V. and Elbaz-Poulichet F. (2003) Bacterial immobilisation and oxidation of arsenic in acid mine drainage (Carnoulès creek, France). Water Res. 37, 2929-2936.

Cornell R. M. and Schwertmann U. (2003) The Iron Oxides. Structure, Properties, Reactions, Occurrence and Uses, 2nd ed. VCH Verlagsgesellschaft $\mathrm{mbH}$, Weinheim.

Duquesne K., Lebrun S., Casiot C., Bruneel O., Personné J.-C., Leblanc M., Elbaz-Poulichet F., Morin G. and Bonnefoy V. (2003) Immobilization of arsenite and ferric iron by Acidithiobacillus ferrooxidans and its relevance to acid mine drainage. Appl. Environ. Microbiol. 69(10), 6165-6173.

Egal M., Casiot C., Morin G., Parmentier M., Bruneel O., Lebrun S. and Elbaz-Poulichet F. (2009) Kinetic control on the formation of tooeleite, schwertmannite and jarosite by Acidithiobacillus ferrooxidans strains in an As(III)-rich acid mine water. Chem. Geol. 265, 432-441.

Egal M., Casiot C., Morin G., Elbaz-Poulichet F., Cordier M. A. and Bruneel O. (2010) An updated insight into the natural attenuation of As concentrations in Reigous creek (southern France). Appl. Geochem. 25(12), 1949-1957.

Fendorf S., Eick M. J., Grossl P. and Sparks D. L. (1997) Arsenate and chromate retention mechanisms on goethite. 1. Surface structure. Environ. Sci. Technol. 31, 315-320.

Fernandez-Martinez A., Timon V., Roman-Ross G., Cuello G. J., Daniels J. E. and Ayora C. (2010) The structure of schwertmannite, a nanocrystalline iron oxyhydroxysulfate. Am. Mineral. 95, 1312-1322.

Forsyth J. B., Hedley I. J. and Johnson C. E. (1968) The magnetic structure and hyperfine field of goethite $(\alpha-\mathrm{FeOOH}) . J$. Phys. $C$ 1, 179-188.

Foster A. L., Brown, Jr., G. E., Tingle T. N. and Parks G. A. (1998) Quantitative arsenic speciation in mine tailings using Xray absorption spectroscopy. Am. Mineral. 83, 553-568.

Fukushi K., Sasaki M., Sato T., Yanase N., Amano H. and Ikeda H. (2003) A natural attenuation of arsenic in drainage from an abandoned arsenic mine dump. Appl. Geochem. 18, 1267-1278.

Fukushi K., Sato T., Yanase N., Minato J. and Yamada H. (2004) Arsenate sorption on schwertmannite. Am. Mineral. 89, 17281734.

Hawthorne F. C. (1976) Hydrogen positions in scorodite. Acta Crystallogr. B 32, 2891-2892.

Hohmann C., Morin G., Ona-Nguema G., Guigner J. M., Brown, , G. E. and Kappler A. (2011) Molecular-level modes of As binding to $\mathrm{Fe}(\mathrm{III})$ (oxyhydr)oxides precipitated by the anaerobic nitrate-reducing $\mathrm{Fe}(\mathrm{II})$-oxidizing Acidovorax sp. strain BoFeN1. Geochim. Cosmochim. Acta 75(17), 4699-4712.

Inskeep W. P., Macur R. E., Harrison G., Bostick B. C. and Fendorf S. (2004) Biomineralization of $\mathrm{As}(\mathrm{V})$-hydrous ferric oxyhydroxide in microbial mats of an acid-sulfate-chloride geothermal spring, Yellowstone National Park. Geochim. Cosmochim. Acta 68, 3141-3155.

Jambor J. L. and Blowes D. W. (1994) The Environmental Geochemistry of Sulphide Mine-Wastes. Short Course Handbook 22, Mineralogical Association of Canada, Nepean, Ontario.

Jiang D. T., Chen N., Demopoulos G. P. and Rowson J. W. (2010) Response to the comment by D. Paktunc on "structural characterization of poorly-crystalline scorodite, iron(III)-arsenate co-precipitates and uranium mill neutralized raffinate solids using X-ray absorption fine structure spectroscopy". Geochim. Cosmochim. Acta 74, 4597-4602.

Leblanc M., Achard B., Benothman D., Bertrand-Sarfati J., Luck J. M. and Personné J.-Ch. (1996) Accumulation of arsenic from acidic mine waters by ferruginous bacterial accretions (stromatolites). Accumulation of arsenic from acidic mine waters by ferruginous bacterial accretions (stromatolites). Appl. Geochem. 11, $541-554$.

Lebrun S. (2004) Minéralogie des Précipités Hydratés Fe-As dans un Drainage Minier Acide: Rôle des Micro-organismes acidophiles. Ph. D. thesis, University Pierre et Marie Curie, Paris 6.

Loan M., Cowley J. M., Hart R. and Parkinson G. M. (2004) Evidence on the structure of synthetic schwertmannite. Am. Mineral. 89(11-12), 1735-1742.

Maillot F., Morin G., Wang Y., Bonnin D., Ildefonse P., Chaneac C. and Calas G. (2011) New insight into the structure of nanocrystalline ferrihydrite: EXAFS evidence for tetrahedrally coordinated $\mathrm{Fe}^{3+}$. Geochim. Cosmochim. Acta 75(10), 27082720.

Majzlan J. and Myneni S. C. B. (2005) Speciation of iron and sulfate in acid waters: aqueous clusters to mineral precipitates. Environ. Sci. Technol. 39, 188-194.

Manning B. A., Fendorf S. E. and Goldberg S. (1998) Surface structures and stability of arsenic(III) on goethite: spectroscopic evidence for inner-sphere complexes. Environ. Sci. Technol. 32, 2383-2388.

Morin G., Juillot F., Casiot C., Bruneel O., Personné J.-C., ElbazPoulichet F., Leblanc M., Ildefonse Ph. and Calas G. (2003) Bacterial formation of tooeleite and mixed arsenic(III) or arsenic(V)-iron(III) gels in the Carnoulès acid mine drainage, France. A XANES, XRD and SEM study. Environ. Sci. Technol. 37, 1705-1712.

Morin G. and Calas G. (2006) Arsenic in soils, mine tailings, and former industrial sites. Elements 2(2), 97-101.

Morin G., Rousse G. and Elkaim E. (2007) Crystal structure of tooeleite, a new iron arsenite hydroxysulfate relevant of acid mine drainage. Am. Mineral. 92, 193-197.

Morin G., Ona-Nguema G., Wang Y., Menguy N., Juillot F., Proux O., Guyot F., Calas G. and Brown, Jr., G. E. (2008) Extended Xray absorption fine structure analysis of arsenite and arsenate adsorption on maghemite. Environ. Sci. Technol. 42, 2361-2366.

Nishimura T. and Robins R. G. (2008) Confirmation that tooeleite is a ferric arsenite sulfate hydrate, and is relevant to arsenic stabilization. Minerals Eng. 21, 246-251.

Nordstrom D. K. and Alpers C. N. (1999) The environmental geochemistry of mineral deposits. In Rev. Econ. Geol. $6 \mathrm{~A} \mathrm{Soc.}$ Econ. (eds. G. S. Plumlee and M. J. Logsdon). Geol. Inc., Littleton $\mathrm{CO}$.

Ona-Nguema G., Morin G., Juillot F., Brown, Jr., G. E. and Calas G. (2005) EXAFS analysis of Arsenic(III) sorption onto 2-line ferrihydrite, hematite, gothite, and lepidocrocite under anoxic conditions. Influence of the surface structure. Environ. Sci. Technol. 39(23), 9147-9155.

Paikaray S., Göttlicher J. and Peiffer S. (2011) Removal of As(III) from acidic waters using schwertmannite: surface speciation and effect of synthesis pathway. Chem. Geol. 283, 134-142. 
Paktunc D., Dutrizac J. and Gutsman V. (2008) Synthesis and phase transformation involving scorodite, ferric arsenate and arsenical ferrihydrite: implications for arsenic mobility. Geochim. Cosmochim. Acta 72, 2649-2672.

Paktunc D. (2010) Comment on "structural characterization of poorly-crystalline scorodite, iron(III)-arsenate co-precipitates and uranium mill neutralized raffinate solids using X-ray absorption fine structure spectroscopy" by N. Chen, D.T. Jiang, J. Cutler, T. Kotzer, Y.F. Jia, G.P. Demopoulos, and J.W. Rowson. Geochim. Cosmochim. Acta 74, 4589-4596.

Perfetti E., Pokrovski G. S., Ballerat-Busserolles K., Majer V. and Gibert F. (2008) Densities and heat capacities of aqueous arsenious and arsenic acid solutions to $350^{\circ} \mathrm{C}$ and $300 \mathrm{bar}$, and revised thermodynamic properties of $\mathrm{As}(\mathrm{OH}) 3^{\circ}{ }_{(\mathrm{aq})}$, $\mathrm{AsO}(\mathrm{OH}) 3^{\circ}{ }_{(\mathrm{aq})}$ and iron sulfarsenide minerals. Geochim. Cosmochim. Acta 72, 713-731.

Pierce M. L. and Moore C. B. (1982) Adsorption of arsenite and arsenate on amorphous iron hydroxide. Water Res. 16, 12471253.

Pokrovski G. S., Schott J., Farges F. and Hazemann J. L. (2003) Iron (III)-silica interactions in aqueous solution: insights from X-ray absorption fine structure spectroscopy. Geochim. Cosmochim. Acta 67, 3559-3573.

Pokrovsky O. S., Pokrovski G. S., Schott J. and Galy A. (2006) Experimental study of germanium adsorption on goethite and germanium coprecipitation with iron hydroxide: X-ray absorption fine structure and macroscopic characterization. Geochim. Cosmochim. Acta 70, 3325-3341.

Post J. E., Heaney P. J., Von Dreele R. B. and Hanson J. C. (2003) Neutron and temperature-resolved synchrotron X-ray powder diffraction study of akaganeite. Am. Mineral. 88(5-6), 782-788.

Ravel B. and Newville M. (2005) ATHENA, ARTEMIS, HEPHAESTUS: data analysis for X-ray absorption spectroscopy using IFEFFIT. J. Synch. Rad. 12, 537-541.
Raven K. P., Jain A. and Loeppert R. H. (1998) Arsenite and arsenate adsorption on ferrihydrite: kinetics, equilibrium, and adsorption envelopes. Environ. Sci. Technol. 32, 344-349.

Rose J., Manceau A., Bottero J. Y., Masion A. and Garcia F. (1996) Nucleation and growth mechanisms of Fe oxyhydroxide in the presence of $\mathrm{PO}_{4}$ ions. 1. Fe K-edge EXAFS study. Langmuir 12, 6701-6707.

Savage K. S., Tingle T. N., O’Day P. A., Waychunas G. A. and Bird D. K. (2000) Arsenic speciation in pyrite and secondary weathering phases, Mother Lode Gold District, Tuolumne County, California. Appl. Geochem. 15, 1219-1244.

Testemale D., Pokrovski G. S. and Hazemann J. L. (2011) Speciation of AsIII and AsV in hydrothermal fluids by in situ X-ray absorption spectroscopy. Eur. J. Mineral. 23, 379.

Vaughan D. J. (2006) Arsenic. Elements 2, 71-75.

Waychunas G. A., Davis J. A. and Fuller C. C. (1995a) Geometry of sorbed arsenate on ferrihydrite and crystalline $\mathrm{FeOOH}$ : reevaluation of EXAFS results and topological factors in predicting sorbate geometry, and evidence for monodentate complexes. Geochim. Cosmochim. Acta 59, 3655-3661.

Waychunas G. A., Rea B. A., Fuller C. C. and Davis J. A. (1993) Surface chemistry of ferrihydrite: Part 1. EXAFS studies of the geometry of coprecipitated and adsorbed arsenate. Geochim. Cosmochim. Acta 57, 2251-2269.

Waychunas G. A., Xu N., Fuller C. C., Davis J. A. and Bigham J. M. (1995b) XAS study of $\mathrm{AsO}_{4}{ }^{3-}$ and $\mathrm{SeO}_{4}{ }^{2-}$ substituted schwertmannites. Physica B 208\&209, 481-483.

Webb S. M. (2005) SIXpack: a graphical user interface for XAS analysis using IFEFFIT. Phys. Scr. T115, 1011.

Winterer M. (1996) The XAFS package. Proc. 9th Internat. Conf. X-ray Absorption Fine Structure (XAFS VI, Grenoble), 144. 